United States Department of the Interior Geological Survey

\title{
NATIONAL EARTHQUAKE INFORMATION CENTER SEMI-ANNUAL TECHNICAL REPORT \\ VOLUME 1 NUMBER 1
}

\author{
Open-File Report 88-384 \\ 1988 \\ National Earthquake Information Center \\ U.S. Geological Survey \\ Denver, Colorado
}

This report is preliminary and has not been reviewed for conformity with U.S. Geological Survey editorial standards. 
A. Teleseismic and Near-field Analysis of the Nahanni Earthquakes in the Northwest Territories, Canada

B. Inversion of Strong-Motion Data for Fault-Slip Distribution during the 1985 Michaocan, Mexico, Earthquake

A. National Earthquake Information Service

B. Broadband Seismogram Analysis

C. Seismicity Maps

D. U.S. Earthquakes Project

E. National Seismograph Network

IV. APPENDIX A 


\section{INTRODUCTION}

This is the first of a series of publications that will report on current seismological research being conducted at the National Earthquake Information Center (NEIC) of the U.S. Geological Survey, Department of the Interior, in Golden, Colorado. General information on data services available from the NEIC will also be included in a separate Operations section that will incorporate progress reports and updates of the various seismograph networks supported by the USGS. Initially, the report will appear on a semi-annual basis, but will be published more often if it becomes necessary.

This first issue contains several short articles describing some of the studies currently in progress at the NEIC. One of the articles, which was contributed by G. Choy and J. Boatwright, describes the estimation of the source parameters for the Nahanni earthquakes from an analysis of the teleseismic digital broadband data and the near-source strong ground motions recorded for the events. Another entry, by C. Mendoza and S. Hartzell, describes the linear inversion of strong-motion velocity records to infer the distribution of coseismic slip during the 1985 Michaoacan, Mexico, earthquake. In addition, D. Gordon reports on the isoseismal data available for a large historic earthquake in the eastern U.S.

Descriptions of the seismological services available from the NEIC are also included in this issue. These are presented in the Operations section together with a discussion of current procedures being utilized by the NEIC for analyzing broadband seismograms and a report of NEIC seismicity maps currently available. In addition, the digital-data information previously contained in the NEIC newsletter will be presented in this section under the heading "Global Digital Seismic Data". In future issues, the Operations section of this report will continue to provide information pertinent to NEIC operations, including status information and updates on the digital-data services available from the NEIC.

Carlos Mendoza 
RESEARCH AND DEVELOPMENT 


\section{TELESEISMIC AND NEAR-FIELD ANALYSIS OF THE NAHANNI EARTHQUAKES IN THE NORTHWEST TERRITORIES, CANADA}

\section{G. L. Choy and J. Boatwright}

The analysis of the Nahanni earthquakes of October 5, $1985\left(M_{S} 6.6\right)$ and December 23, $1985\left(M_{S} 6.9\right)$ will have important implications for the assessment of seismic hazards in intraplate environments. To maximize the information available to seismic engineers, broadband data recorded teleseismically are analysed jointly with strong-motion data recorded in the near field. The time-domain analysis of teleseismic data yields the source mechanisms, depths and complexities of rupture of each earthquake. Both earthquakes occurred as shallow thrusts with centroid depths $(6-7 \mathrm{~km})$ and shallowly dipping fault planes that correspond well with the aftershock distributions obtained from a local survey run by the Canadian Geological Survey. The shallow nodal plane for the October 5 earthquake dips $30^{\circ}$ to the WSW, while the shallow nodal planes of the subevents for the December 23 earthquake dip an average of $23^{\circ}$ to the WSW. The October 5 earthquake has an impulsive initial rupture, followed by a weak subevent of longer duration but smaller moment release. The December 23 earthquake exhibits more complexity, being comprised of three subevents of similar size. The subevent delays derived from the teleseismic analysis are used to help interpret arrivals in records of ground velocity recorded in the near field of the December 23 earthquake. The rupture geometries inferred from the joint near- and farfield analysis suggests that the rupture processes were unusually complicated and that the $2 g$ peak that occurs late in one of the near-field records could be a localized phenomenon. Spectral analyses of the teleseismic $P$ waves yield the following source parameters for the October 5 and December 23 earthquakes, respectively: the seismic moments are 1.2 and $1.8 \times 10^{19} \mathrm{Nm}$, the radiated energies are 1.8 and $2.8 \times 10^{14} \mathrm{Nm}$, and the dynamic stress drops are 65 and 50 bars. The acceleration source spectra of both earthquakes exhibit an intermediate slope $\left(\left|\vec{u}_{\alpha}(\omega)\right| \propto \omega\right)$ from 0.03 to $0.3 \mathrm{~Hz}$, suggesting that the earthquakes represent the failure of asperities. Extrapolating the teleseismic P-wave spectra to estimate the near-field S-wave spectra yields good fits to the acceleration spectra from two strong motion records, but underestimates the spectra from a third strong motion record with the strongest, but possibly localized, accelerations. 


\title{
INVERSION OF STRONG-MOTION DATA FOR FAULT-SLIP DISTRIBUTION DURING THE 1985 MICHOACAN, MEXICO, EARTHQUAKE
}

\author{
C. Mendoza and S. H. Hartzell
}

The strong-motion data recorded for the 19 September $1985\left(8.1 M_{S}\right)$ Michoacan, Mexico, earthquake has been presented by Anderson et al. (1986). We have analyzed selected velocity records from this data set to recover the distribution of coseismic slip on the fault using the point-by-point inversion method of Hartzell and Heaton (1983). Initially, we fixed the strike and dip of the fault plane at $300^{\circ}$ and $14^{\circ}$, respectively, and then divided the fault into 120 subfaults of equal size. Assuming a radial propagation of rupture at a constant velocity away from a fixed hypocenter, synthetic ground motions were then computed for each subfault at each strong-motion site for uniform strike-slip and dip-slip displacements. We then inverted for the amounts of strike-slip and dip-slip displacement required of each subfault to reproduce the observed velocity records. These slip values were subsequently contoured to obtain a map of the slip variation on the fault.

The distribution of slip bears a strong resemblance to the slip model previously obtained from an inversion of the teleseismic $P$ waveforms (cf. Mendoza and Hartzell, 1988). Both the strong-motion and teleseismic data require the failure of at least three different large asperities distributed within a $180-\mathrm{km}$ segment of the Cocos-North American plate boundary. As in the teleseismic result, the strong-motion model shows mainly dip-slip displacement with a small and relatively insignificant component of right-lateral strike-slip motion. The dip-slip components of displacement for the two models are shown in Figure 1. A notable difference in the two distributions is the major source located near the hypocenter. This source is farther down-dip of the hypocenter in the strong-motion model than in the teleseismic model. This difference could be due either to a lack of resolution in the down-dip direction for the teleseismic data or to large errors in the timing of the strong-motion records. A simultaneous inversion, incorporating both the teleseismic waveforms and the near-source ground motions, should provide additional constraints on the variation of slip across the fault for the Michoacan earthquake.

\section{REFERENCES}

Hartzell, S.H. and T.H. Heaton, 1983, Inversion of strong ground motion and teleseismic waveform data for the fault rupture history of the 1979 Imperial Valley, California, earthquake, Bull. Seism. Soc. Am., v. 73, p. 1553-1583.

Anderson, J.G., P. Bodin, J.N. Brune, J. Prince, S.K. Singh, R. Quaas, and M. Onate, 1986, Science, v. 233, p. 1043-1049.

Mendoza, C. and S.H. Hartzell, 1988, Inversion for slip distribution using teleseismic P waveforms: North Palm Springs, Borah Peak, and Michoacan earthquakes, Bull. Seism. Soc. Am., v. 78, p. 1092-1111. 


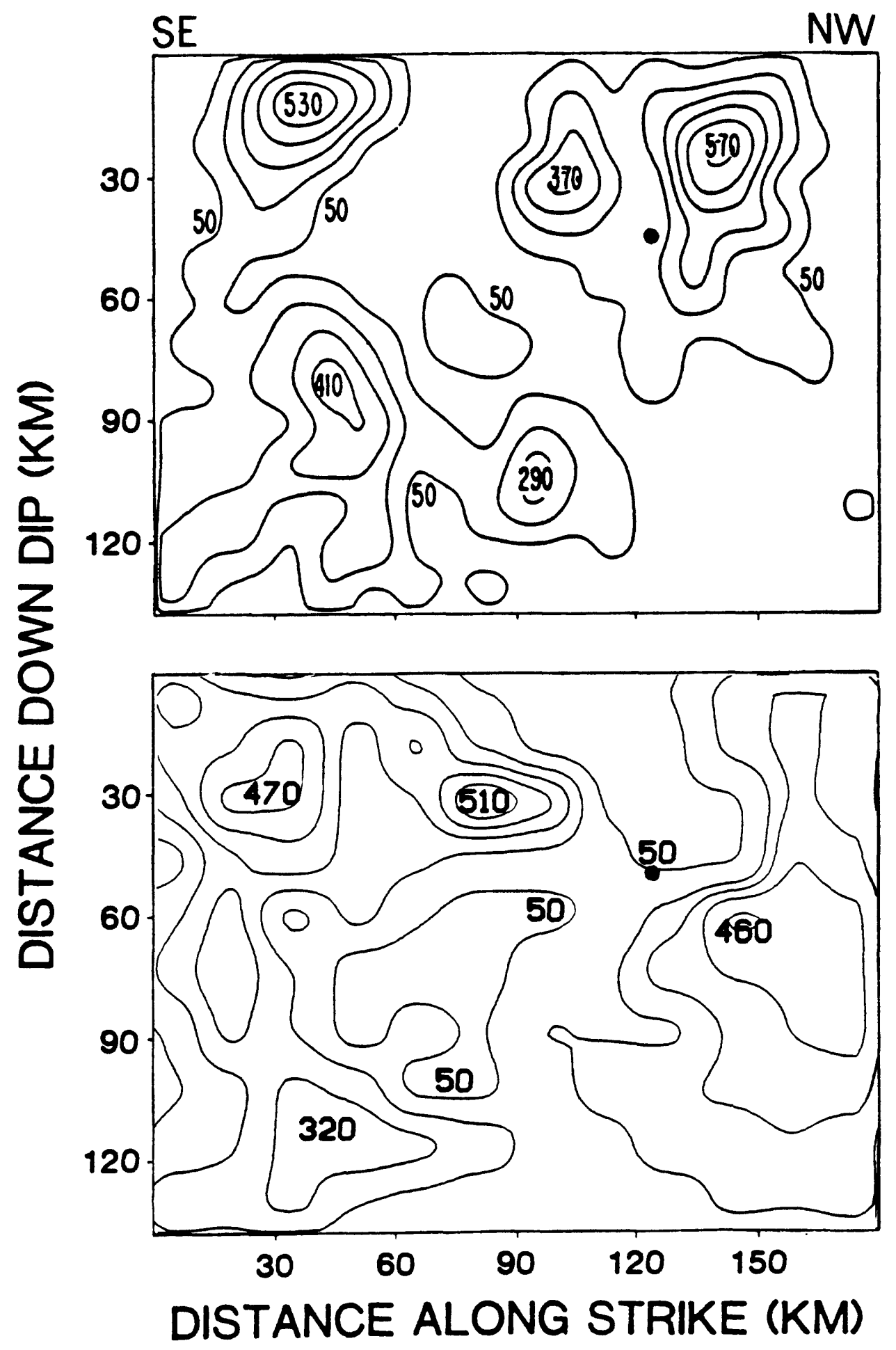

Figure 1. Distribution of coseismic dip-slip ( $90^{\circ}$ rake) displacement computed for the 1985 Michoacan, Mexico, earthquake using teleseismic data (Top) and selected strong-motion velocity records (Bottom). Slip is contoured at $100-\mathrm{cm}$ intervals beginning at the $50-\mathrm{cm}$ level. The filled circle, which represents the hypocenter, is at a depth of $17 \mathrm{~km}$. 
The National Earthquake Information Center (NEIC) retains a keen interest in the historical development of earthquake seismology. The accompanying map (Figure 2) may represent the first, contemporary isoseismal map of an earthquake in the United States. These isoseismals, which were compiled by Rockwood (1885), correspond to an earthquake near the New York-New Jersey border on August 10, 1884.

Drawn on the basis of a 6-element intensity scale of Professor Rockwood's design, the isoseismals represent over 200 intensity observations. The outermost isoseismal encloses the total felt area. The innermost isoseismal surrounds an elliptically shaped area, about $300 \mathrm{~km}$ long and $100 \mathrm{~km}$ wide, where ground motion cracked plaster and threw bricks down from chimneys. The innermost isoseismal also exhibits the northeast-southwest elongation that characterizes more recent shocks in the area.

The isoseismals of the 1884 shock engender more than scientific curiosity. The possible effects of a repeat of the 1884 earthquake must be considered relative to the fact that over 20 million people now reside in the area of light architectural damage (MM VI to VII) associated with the 1884 shock. Furthermore, since early Colonial times, about 10 earthquakes with maximum intensity as high or higher than the 1884 shock have occurred in the urban corridor between Boston and Washington, D.C. A shock similar to the 1884 event would affect a large number of people were it to occur anywhere along this corridor.

\section{REFERENCES}

Rockwood, C. G., 1885, Notes on American earthquakes: American Journal of Science (Third Series), v. 29, p. 425-437.

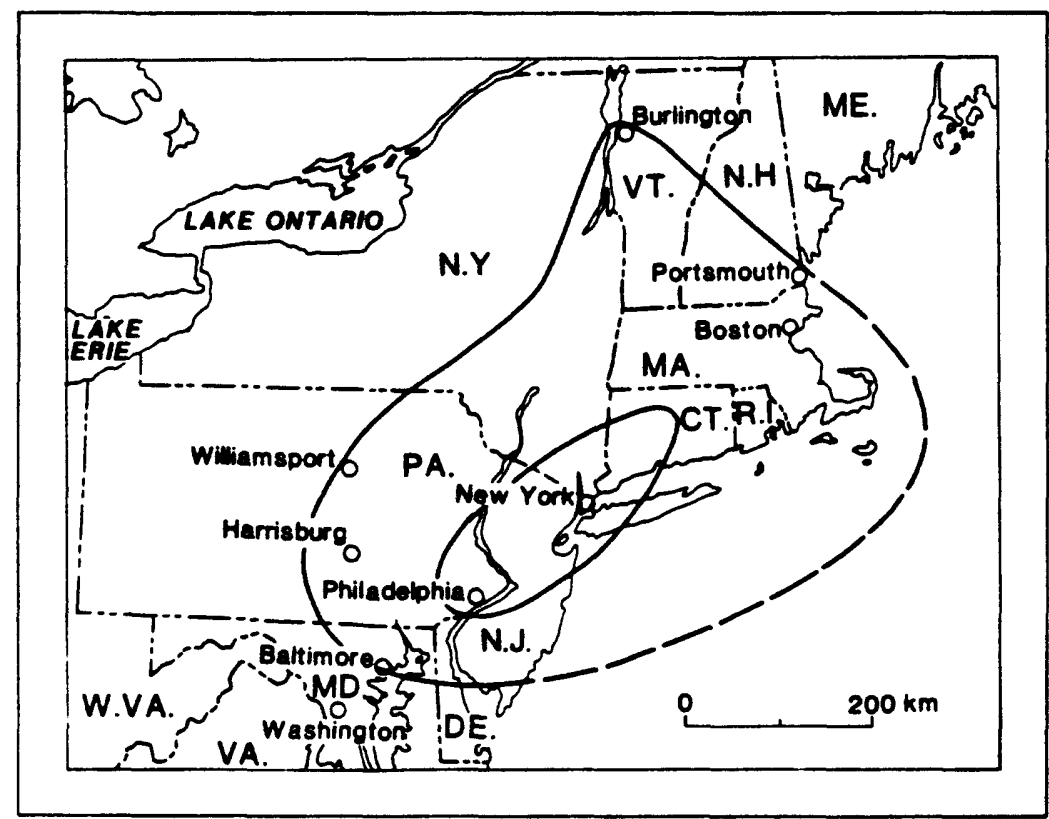

Figure 2. Isoseismals of the New York - New Jersey earthquake of August 10, 1884. The outer isoseismal surrounds the felt area and the inner isoseismal encloses the area characterized by light damage, cracked plaster and bricks thrown from chimneys (modified from Rockwood, 1885). 
OPERATIONS 


\section{NATIONAL EARTHQUAKE INFORMATION SERVICE}

The National Earthquake Information Service (NEIS) forms a major part of the operational responsibilities of the National Earthquake Information Center (NEIC). The NEIS is the foremost collector of rapid earthquake information in the world and has two basic responsibilities: the Earthquake Early Alerting Service (EEAS) and the publication and dissemination of earthquake data.

The EEAS is a 24-hour-a-day service which requires the NEIS to determine the location and magnitude of significant earthquakes in the United States and around the world as rapidly and accurately as possible and to communicate this information to interested persons or groups. The information is given to federal and state government agencies who are responsible for emergency responses, to government public information channels, to national and international news media, to scientific groups including groups planning aftershock studies, and to private citizens who request information. In the case of a damaging earthquake in a foreign country, the information is passed to the staffs of the American embassies and consulates in the affected countries and to the United Nations Disaster Relief Organization (UNDRO).

The EEAS is activated by an alarm in the NEIC office, triggered when recorded ground motion exceeds a threshold level at four seismograph stations in the western United States. Signals from the stations are telemetered to the NEIS operations center in Golden. The alarm is triggered by an earthquake that registers at least 4.5 on the Richter Scale in the contiguous United States, 5.5 in Alaska, Latin America, and Japan, and 6.5 anywhere else in the world. The service can also be invoked upon visual observation of an incoming seismic signal on the recorders in the instrument room or by a felt report telephoned to the NEIC headquarters by the news media, by government-agency personnel, or by private citizens. The service also collaborates with the Pacific and Alaska Tsunami Warning Service.

When an earthquake occurs and the alarm is triggered, the geophysicists on standby duty are notified. After entering the operations center, the geophysicists scale arrival times of "P" waves at selected stations of the U.S. Seismic Network. A preliminary epicenter, magnitude and origin time are computed from the network data using NEIS computer programs. The geophysicists then prepare a "release" on the earthquake send it via several telecommunications networks to the news media, other government agencies, disaster relief organizations, and foreign governments. Key civil defense agencies are notified by telephone over the National Warning System, and telephone calls from the news media and other interested persons are answered.

The NEIS relies on a variety of seismic reporting networks throughout the world to gather data. The most rapid data to arrive are from the approximately 100 stations of the U.S. Seismic Network. which are recorded in the Golden operations center as the events actually occur. The U.S. Seismic Network includes stations spread across the contiguous United States, Alaska, Hawaii, and Norway. Signals are transmitted to Golden via telephone line and satellite. An arrangement with the European-Mediterranean Seismological Centre (CSEM) in Strasbourg, France, enables the NEIS to receive rapid data telegraphically from additional stations located in Europe. Data from these stations and additional networks and stations associated with governments and universities throughout the world, 
including the People's Republic of China and the USSR, arrive at the NEIS via computer link, telecommunications networks, and airmail. More than 3,000 stations report data to the NEIS; some report regularly and some report only occasionally or for local events.

Additionally, raw seismic data (seismograms) from around the world are received by mail from the Worldwide Standardized Seismographic Network (WWSSN) and the Global Digital Seismograph Network (GDSN) managed by NEIC's Albuquerque Seismological Laboratory (ASL). These networks include about 130 stations operating in 60 countries. The raw data from these networks provide an invaluable complement to the data reports and are distributed by the NEIC to interested scientists. The digital data are routinely subjected to sophisticated computer analysis to determine details of the most important events each month.

The second responsibility of the NEIS is the publication of earthquake data. The NEIS publications are the principal sources of current earthquake information for thousands of seismologists around the world for use in fundamental research and in the evaluation of earthquake hazards. At the present time, the NEIS staff locates and publishes approximately 12,000 earthquakes on a yearly basis. These include only the most important of the many million earthquakes which are estimated to occur each year.

The "Quick Epicenter Determinations" (QED), a very preliminary list of earthquakes, is computed daily and is available for computer access by telephone line. The "Preliminary Determination of Epicenters" (PDE) is published and distributed weekly to those agencies contributing data to the NEIS. The PDE "Monthly Listing" is published monthly and is available to the general public on a subscription basis through the Superintendent of Documents in Washington, D.C. The "Earthquake Data Report," also a monthly publication, provides additional and more detailed information and is intended for the use of seismologists on a data-exchange basis. The Monthly Listing and the EDR each contain about 900 to 1200 events each month.

Waverly J. Person 


\section{BROADBAND SEISMOGRAM ANALYSIS}

Since October 1985, the Monthly Listings of the PDE have published estimates of depth from broadband seismograms. Occasionally, the Comments in the Monthly Listings have also included remarks on the complexity of earthquake rupture. It is the purpose of this section to describe in greater detail than is possible within the Monthly Listings the features on the seismograms from which depth and rupture complexity have been inferred. In each issue of this Semi-Annual Report, this section will be devoted to the discussion of selected earthquakes.

The NEIS routinely interprets broadband data from the GDSN and other networks that contribute to the Event Tape. The advantages of using broadband records for teleseismic analysis have been discussed by Choy and Boatwright (1981). As a result of the broad bandwidth in the data, there is often sufficient resolution in the waveforms to distinguish source functions and depth phases by direct inspection. Methods of interpretation have been described by Choy et al. (1983) and Choy and Engdahl (1987). An example is shown in Figure 3 for a deep earthquake from the Sea of Okhotsk. Three representations of the $\mathrm{P}$ wave recorded at station $\mathrm{KEV}$ are shown. The top trace shows the raw short-period record. The next two traces show broadband displacement and velocity. Depth phases are evident only in the broadband records. Moreover, rupture complexity can be inferred from the double trough in the direct $P$ wave. The inversion of differential travel times of P-pP and P-sP from 10 stations yielded a depth from broadband records of $542 \mathrm{~km}$. A depth obtained from broadband analysis is identified in the Monthly Listings by the phrase: "Depth from broadband displacement seismograms".

The NEIS will not assign a broadband depth to an earthquake if phases cannot be clearly identified. This is often the case for waveforms from large complex ruptures. Such waveforms cannot be interpreted without the assistance of synthetic seismograms. Nevertheless, the broadband data often reveal direct information on crucial features of the rupture process which may have some impact on the seismological and tectonic assessment of an earthquake. An example is the large $\left(M_{S}\right.$ 7.6) earthquake that occurred in the Gulf of Alaska on 18 May 1987. The description in the Monthly Listings for this earthquake states that it was "a complex event, with major subevent occurring about 15 seconds after the onset of the foreshock, observed on broadband displacement seismograms." Figure 4 illustrates the basis for this comment. In the top two traces of Figure 4, a typical shortperiod record generated by the main shock is shown at two magnifications. The entire $P$ wave appears to be an undistinguished cascade of $1 \mathrm{~Hz}$ energy that monotonically changes in amplitude over the next minute. The initial arrival would normally be considered the onset of the main shock. (Note that the signal from a foreshock of $m_{b} 4.5$ is too small to be seen on this record.) However, as seen in the broadband displacement and velocity records, the $P$ wave is composed of two parts. The initial part is relatively insignificant compared to the major release of moment and energy that arrives $16 \mathrm{~s}$ later (or $20 \mathrm{sec}-$ onds after the foreshock). Following the convention of Choy and Dewey (1988), we have labeled the initial small burst of energy as the $m s$ or minor subevent of the main shock. The major subevent is identified as $M S$. The arrival of $M S$ could be clearly identified on the broadband records from 9 stations. The differential times between $M S$ and $m s$, ranging from $11 \mathrm{~s}$ to $17 \mathrm{~s}$, appeared to show a systematic variation with azimuth. As seen in the 
velocity records, the energy of the $m s$ arrival is substantially smaller than the energy in the large $M S$ arrival. This relationship would not be discernable if based entirely on measurements from bandlimited short-period data. The radiated energy, as computed from the broadband data using the method of Boatwright and Choy (1986), is $2.7 \pm 0.5 \times 10^{17}$ $\mathrm{Nm}$.

George L. Choy Bruce W. Presgrave

\section{REFERENCES}

Boatwright, J. and G. L. Choy, 1986, Teleseismic estimates of the energy radiated by shallow earthquakes, J. Geophys. Res., v. 91, p. 2095-2112.

Choy, G. L. and J. Boatwright, 1981, The rupture characteristics of two deep earthquakes inferred from broadband GDSN data, Bull. Seismol. Soc. Am., v. 71, p. 691-711.

Choy, G.L., J. Boatwright, J.W. Dewey, and S.A. Sipkin, 1983, A teleseismic analysis of the New Brunswick earthquake of January 9, 1982, J. Geophys. Res., v. 88, p. 2199-2212.

Choy, G. L. and E. R. Engdahl, 1987, Analysis of broadband seismograms from selected IASPEI events, Phys. Earth and Planet. Int., v. 47, p. 80-92.

Choy, G.L. and J.W. Dewey, 1988, Rupture process of an extended earthquake sequence: Teleseismic analysis of the Chilean earthquake of 3 March 1985, J. Geophys. Res., v. 93, p. 1103-111. 


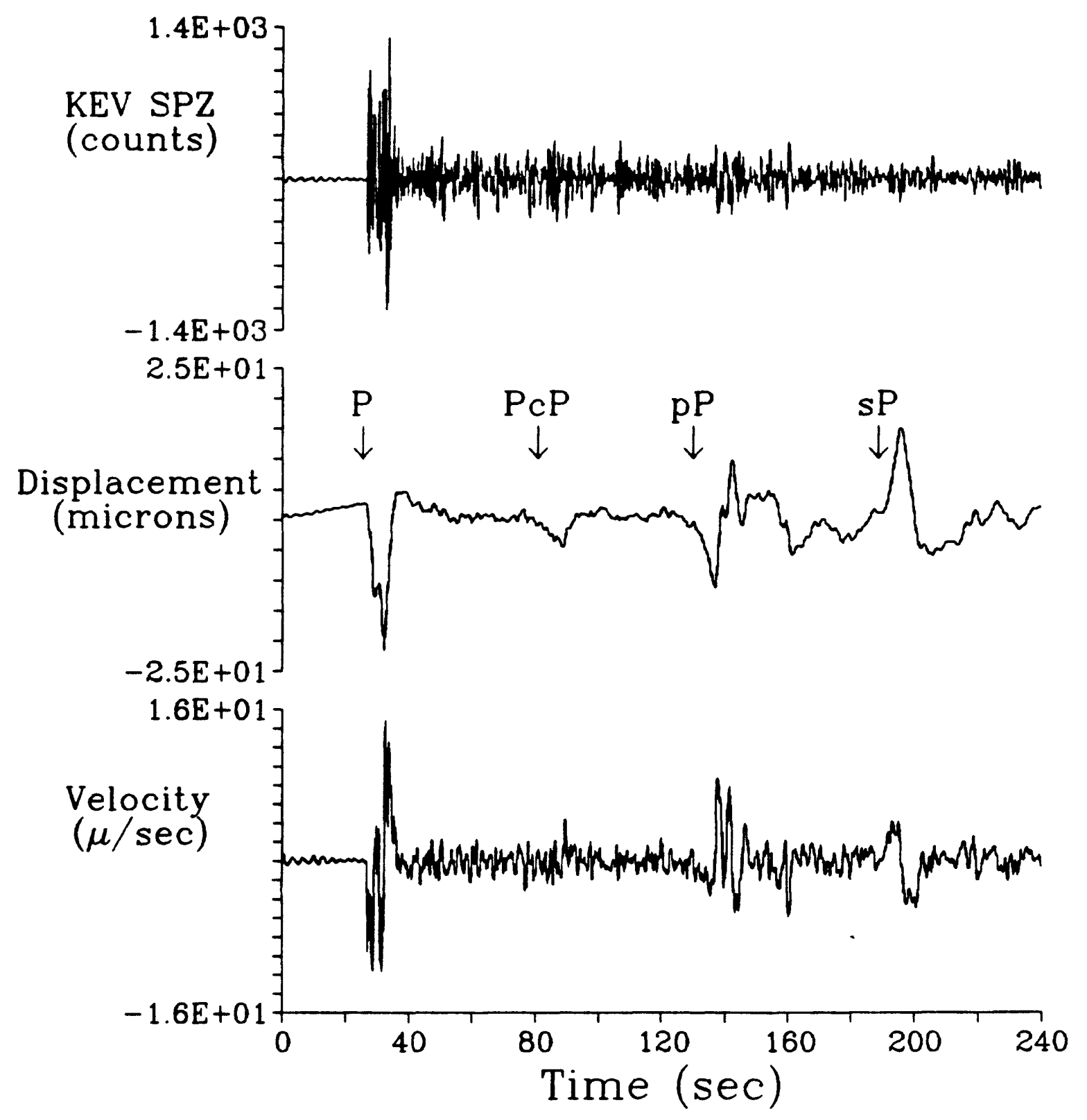

Figure 3. P-wave data recorded at KEV from the deep Sea of Okhotsk earthquake of 18 May 1987 (NEIC origin time $03 \mathrm{~h} 07 \mathrm{~m} 34.1 \mathrm{~s} ; 49.282^{\circ} \mathrm{N}, 147.693^{\circ} \mathrm{E} ; \mathrm{m}_{b} 6.1$; broadband depth $542 \mathrm{~km}$ ). (Top) The raw short-period record. (Middle) The corresponding broadband displacement record. (Bottom) The corresponding broadband velocity record. 

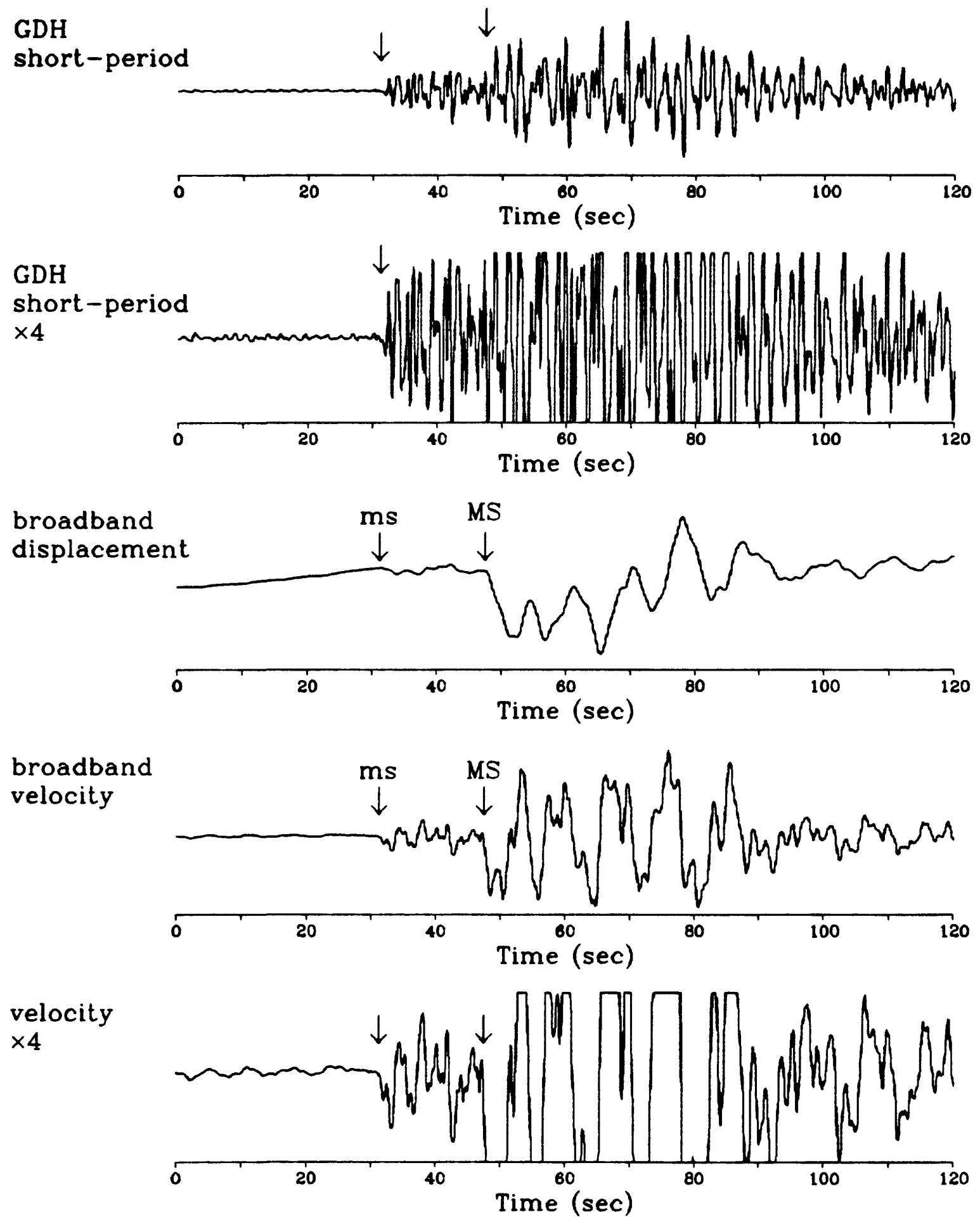

Figure 4. The P-wave data recorded at GDH for the large Gulf of Alaska earthquake of 30 November 1987 (NEIC origin time $19 \mathrm{~h} 23 \mathrm{~m} 19.5 \mathrm{~s} ; 58.679^{\circ} \mathrm{N}, 142.786^{\circ} \mathrm{W} ; m_{b} 6.7, M_{S} 7.6$ ). (Top) The short-period $P$ wave from $G D H$. (Second trace) The short-period $P$ wave magnified four times. (Third trace) The broadband displacement record. The event $m s$ is relatively small compared to the $M S$ event that arrives $11 \mathrm{~s}$ later. (Fourth trace) The broadband velocity record. (Bottom) The velocity record magnified 4 times. 


\section{SEISMICITY MAPS}

The National Earthquake Information Center (NEIC) has published a set of three global seismicity maps in the Geophysical Investigation Series of the U.S. Geological Survey (USGS). One of the maps (GP-989) contains the global distribution of seismicity for the yeafs 1977 to 1986 . The other two maps include focal-mechanism data for large earthquakes that occurred in the years 1981 to 1985 . One of the focal-mechanism maps (GP-990) contains first-motion fault-plane solutions determined by the NEIC. The other mechanism map (GP-991) contains the NEIC moment-tensor source mechanisms. The maps can be obtained from the Map Sales section of the U.S. Geological Survey. In addition, microfiche and photographic slides $(35-\mathrm{mm})$ of the maps have been produced. These, as well as a limited number of the wall-size maps, are available from Susan Goter, National Earthquake Information Center, U.S. Geological Survey, Box 25046, MS 967, Denver, Colorado, 80225.

Susan K. Goter 


\section{UNITED STATES EARTHQUAKES PROJECT}

This project, which was first begun by the U.S. Government in 1928 , is concerned with the publication of hypocenters, magnitudes, and damage/effects of earthquakes within the 50 states. The hypocenters and magnitudes are computed in conjunction with the National Earthquake Information Service (NEIS); the damage and effects are compiled from various sources. The principal source is questionnaires mailed to U.S. Postmasters, police departments, fire departments, and volunteers. The information is published in the annual publication, "United States Earthquakes", which contains tables of earthquake data, seismicity and isoseismal maps, activities of other organizations, and strong-motion data. These data are primary to the study of seismic risk in the United States.

Another important source of information is the seismic history of the United States. The U.S. Earthquakes Project compiles and publishes a list of all the known hypocenters, magnitudes, and intensities of earthquakes located within the boundaries of each state. These data are updated annually from the "United States Earthquakes" publication. The data are available in three formats: maps, published lists, and computer lists from a search on the Earthquake Data System. The Earthquake Data System consists of two parts. The first part is a data base of worldwide earthquakes compiled from 64 seismic catalogs from the United States and from other countries around the world. It contains entries of approximately 500,000 earthquakes covering the period 2000 B.C. to present and is continuously being updated from new catalogs and from data published by the NEIS. The second part is a computer program that conducts a search of the data base and outputs the earthquake lists. The computer lists can be in three formats: printed output, magnetic tape, or floppy disk. A unique feature of this system is that a user may access the data base via any computer terminal equipped with a modem and telecommunication software.

Carl W. Stover 


\section{NATIONAL SEISMOGRAPH NETWORK}

The frequency of occurrence, geographical distribution, and magnitude of earthquakes are important parameters for assessing the seismic hazard of a region and for establishing the design and construction criteria for critical facilities. These parameters are known collectively as the seismicity of a region and can only be determined through the operation of seismic networks. For many years, scientists and government agencies have recognized the need for a high-quality National Seismograph Network through a cooperative effort between the U.S. Geological Survey (USGS) and the Nuclear Regulatory Commission (NRC). The network is being installed and will be operated by the USGS. The NRC is providing funds to the USGS for the completion of the network east of the Rockies. Funding for the network west of the Rockies is currently under negotiation.

The network will consist of approximately 150 seismic stations distributed across the lower 48 states and across Alaska, Hawaii, Puerto Rico, and the Virgin Islands. This network should provide the capability to detect, locate, and quantify the energy release of earthquakes of magnitude 2.5 and larger in all states except possibly part of Alaska. This capability to characterize earthquakes will be greater than exists today in most parts of the United States. However, the U.S. network will not, even when complete, eliminate the need for additional very dense networks of seismic stations in certain specific locations. Such dense local networks exist today in areas within the United States (for example, in parts of California, Utah, and around the city of St. Louis). The purpose of these dense local networks is to detect earthquakes down to very low magnitude levels (below the magnitude 2.5 threshold of the national network) and to achieve very high location accuracy. The dense, local networks are thus targeted against a few specific identified seismic risk areas with the objective of acquiring data important for research in subjects such as earthquake prediction and ground motion estimation.

Data from the National Network will be of very high quality and will provide, for the first time, near uniform coverage to fairly low magnitude levels for the entire country. All future seismic studies of the United States, including those studies using data from the very dense local networks, can be expected to rely very heavily on the high-quality data base obtained from the National Network. The relationship between the National Seismograph Network and the dense local seismic networks can, therefore, be considered complementary in nature.

Robert P. Masse 


\section{GLOBAL DIGITAL SEISMIC DATA}

Earthquake data recorded by stations of the Global Digital Seismograph Network (GDSN) are routinely collected by the National Earthquake Information Center (NEIC) and made available to the seismological community through various Regional Data Centers located at several universities in the United States and in several other countries. The GDSN network includes Seismic Research Observatory (SRO), abbreviated SRO (ASRO) instruments. and Worldwide Standardized Seismograph Network stations that have been converted to digital recording (DWWSSN). In addition, stations of the Regional Seismic Test Network (RSTN) form part of the digital network, but these stations are currently closed on a temporary basis. The NEIC also collects digital data contributed by other worldwide networks such as the China Digital Seismograph Network (CDSN) and the Network of Autonomous Recording Stations (NARS) and Gräfenburg (GRF) Arrays in western Europe.

In this section, status information pertaining to the digital-data collection program is presented. This information was formerly included in the National Earthquake Information Center Newsletter, which is no longer being published. However, the same general format previously used in the Newsletter is kept here. For example, a current list of the worldwide digital stations that contribute to the network-day and event tapes is included. In addition, a discussion of current modifications to the collection program and recent problems associated with the various digital stations is presented. This includes a comprehensive listing containing information on all stations that have had problems and/or modifications to date. This list will be periodically updated in future publications of this report. This issue also contains detailed information on the Gräfenburg Array, which has not been previously described. 


\begin{tabular}{|c|c|c|c|}
\hline SRO STATIONS & $C O D E$ & $I D$ & INSTALLED \\
\hline Albuquerque, New Mexico & ANMO & 30 & 01 Sep 1974 \\
\hline Ankara, Turkey & ANTO & 31 & 01 Aug 1978 \\
\hline Bogota, Colombia & $\mathrm{BOCO}$ & 32 & 13 Mar 1978 \\
\hline Chiang Mai, Thailand & CHTO & 33 & 01 Jul 1977 \\
\hline Bar-Giyyora, Israel & BGIO & 34 & 15 Apr 1986 \\
\hline Guam, Mariana Islands & GUMO & 35 & 01 Dec 1975 \\
\hline Bangui, Central African Republic & $\mathrm{BCAO}$ & 37 & 12 Jun 1979 \\
\hline Mundaring (Narrogin), Australia & NWAO & 38 & 01 Apr 1976 \\
\hline Gräfenberg, Germany & GRFO & 39 & 01 Oct 1978 \\
\hline Taipei, Taiwan & TATO & 41 & 13 May 1976 \\
\hline $\begin{array}{l}\text { Wellington (South Karori), } \\
\text { New Zealand }\end{array}$ & SNZO & 42 & 15 Mar 1976 \\
\hline \multicolumn{4}{|l|}{ ASRO STATIONS } \\
\hline Charters Towers, Australia & CTAO & 50 & 09 Oct 1976 \\
\hline La Paz (Zongo), Bolivia & ZOBO & 51 & 10 Sep 1976 \\
\hline Matsushiro, Japan & MAJO & 53 & 15 Jun 1977 \\
\hline Kongsberg, Norway & KONO & 54 & 01 Sep 1978 \\
\hline \multicolumn{4}{|l|}{ DWWSSN STATIONS } \\
\hline State College, Pennsylvania & SCP & 61 & 29 Jan 1981 \\
\hline College, Alaska & COL & 62 & $06 \mathrm{Jan} 1982$ \\
\hline Longmire, Washington & LON & 63 & 01 Oct 1980 \\
\hline Columbia College, California & CMB & 64 & 11 Nov 1986 \\
\hline Honolulu, Hawaii & $\mathrm{HON}$ & 66 & 21 Mar 1983 \\
\hline Kevo, Finland & $\mathrm{KEV}$ & 67 & 14 Oct 1981 \\
\hline Afiamalu, Western Samoa & AFI & 69 & 15 May 1981 \\
\hline Godhavn, Greenland & GDH & 70 & 26 Aug 1982 \\
\hline Silverton, South Africa & SLR & 71 & 24 Oct 1981 \\
\hline Brasilia, Brazil & BDF & 72 & 08 Jun 1982 \\
\hline Toledo, Spain & TOL & 73 & 03 Nov 1981 \\
\hline Hobart, Tasmania & TAU & 74 & 10 Jun 1981 \\
\hline Lembang, Indonesia & LEM & 76 & 02 Jun 1982 \\
\hline Kingsbay (Svalbard), Norway & KBS & 79 & 02 Oct 1985 \\
\hline
\end{tabular}


CDSN STATIONS

Beijing, China

Lanzhou, China

Kunming, China

Urumqi, China

Hailar, China

Mudanjiang, China

NARS Array

Goteborg, Sweden

Monsted, Denmark

Logumkloster, Denmark

Witteveen, Netherlands

Dourbes, Belgium

Villiers-Adam, France

Les-Eyzies, France

Arette, France

Ainzon, France

Puertollano, Spain

Granada, Spain

Valkenburg, Netherlands

Clermont-Ferrand, France

Toledo, Spain .

OTHER STATIONS

Glen Almond, Quebec, Canada

NORESS array site A0

Haidhof, Germany

Bruennthal, Germany

Eglofsdorf, Germany

IRIS-1 STATIONS

Harvard, Massachusetts

Pasadena, California
BJI 101

LZH 102

KMI 104

WMQ 107

HIA $\quad 108$

MDJ 109

109

NE01 201

NE02 202

NE03 203

NE04 204

NE06 206

NE07 207

NE09 209

NE10 210

NE11 211

NE13 213

NE14 214

NE15 215

NE16 216

NE17 217

GAC $\quad 43$

NRA0 301

GRA1 302

GRB1 303

GRC1 304

HRV $\quad 510$

IPAS 511
START

Oct 1986

Oct 1986

Oct 1986

Oct 1986

Mar 1987

Oct 1986

START

Sep 1985

Sep 1985

Sep 1985

Sep 1985

Sep 1985

Sep 1985

Sep 1985

Sep 1985

Sep 1985

Sep 1985

Sep 1985

Sep 1985

Sep 1985

Sep 1985

START

26 Apr 1982

Sep 1985

Sep 1985

May 1986

May 1986

START

1 Jan 1988

3 Apr 1988 


\section{THE GRÄFENBERG ARRAY}

The Gräfenberg (GRF) array is a 13-station digital broadband array in the Federal Republic of Germany that extends over a length of approximately $100 \mathrm{~km}$ on the Franconian Jura. Three of the stations (GRA1, GRB1, GRC1) have three components, while the remainder are vertical-component only. The configuration of the array is shown in Figure 5. The system consists of a Streckeisen STS-1 seismometer, an anti-aliasing filter, and a gain-ranging amplifier. The output is then converted with a 15-bit analog-to-digital converter and transmitted to the Seismologisches Zentralobservatorium Gräfenberg (SZGRF), the Gräfenberg Central Seismological Observatory. The broadband output is proportional to ground velocity, with a response that is flat from approximately 0.05 to $5.0 \mathrm{~Hz}$, and is sampled at a rate of 20 sps. The transfer function is shown in Figure 6.

The GRF array was completed and began operation in 1980. The SZGRF is a part of the Bundesanstalt fur Geowissenschaften und Rohstoffe (BGR), the Federal Institute of Geosciences and Natural Resources. The array was built by the BGR with the financial support of the Deutche Forschungsgemeinshaft, the German Research Association.

The data avajlable on the NEIC Network Event Tapes and CD-ROM's are event data from the three 3-component stations that have been windowed according to event size and event-station distance. Continuous data and/or data from the vertical-component stations may be obtained directly from the SZGRF by writing to the Seismologisches Zentralobservatorium, Krankenhausstraße 1-3, D-8520 Erlangen, Federal Republic of Germany. 

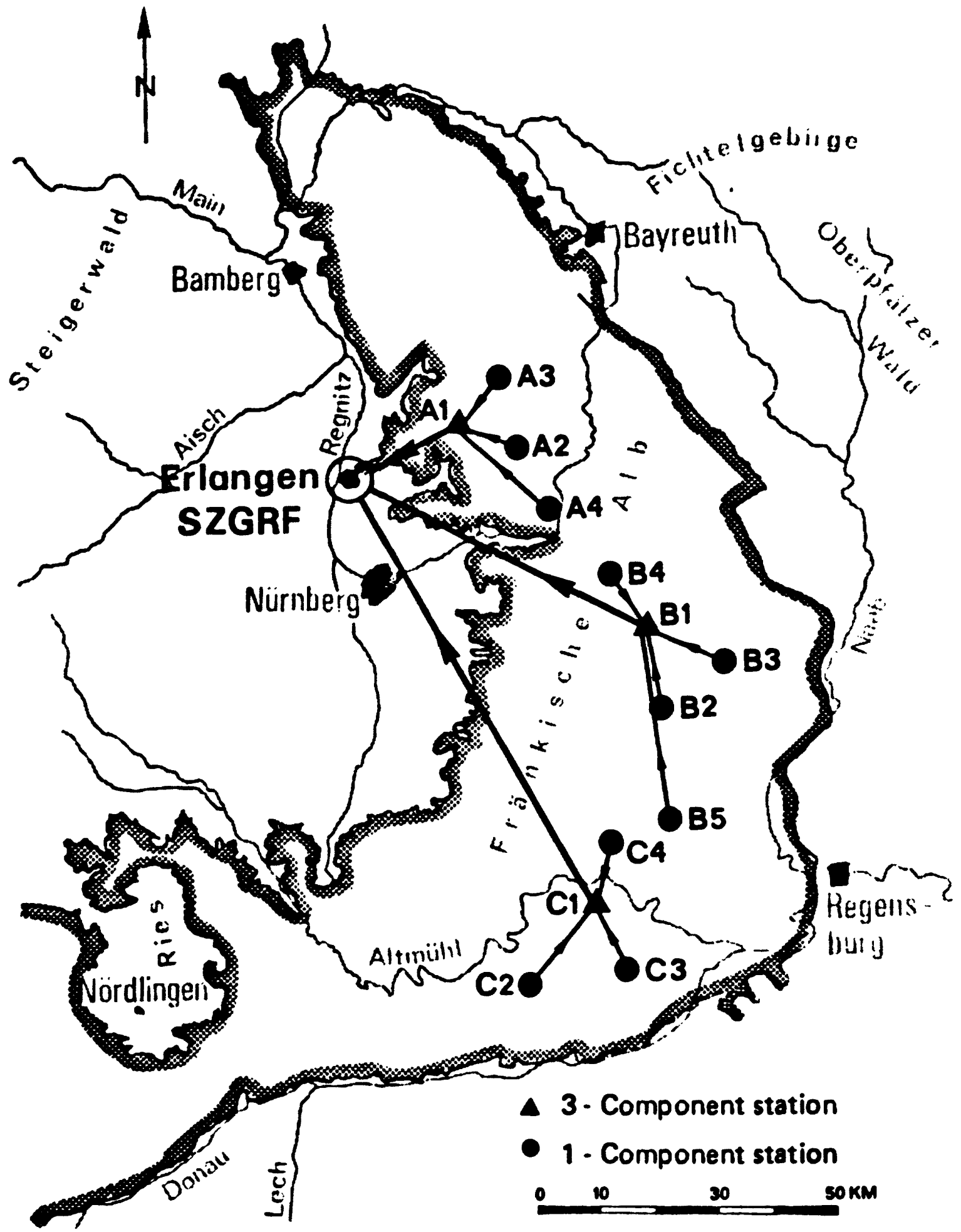

Figure 5. Locations of the seismometer stations and data flow of the Gräfenburg Array. 


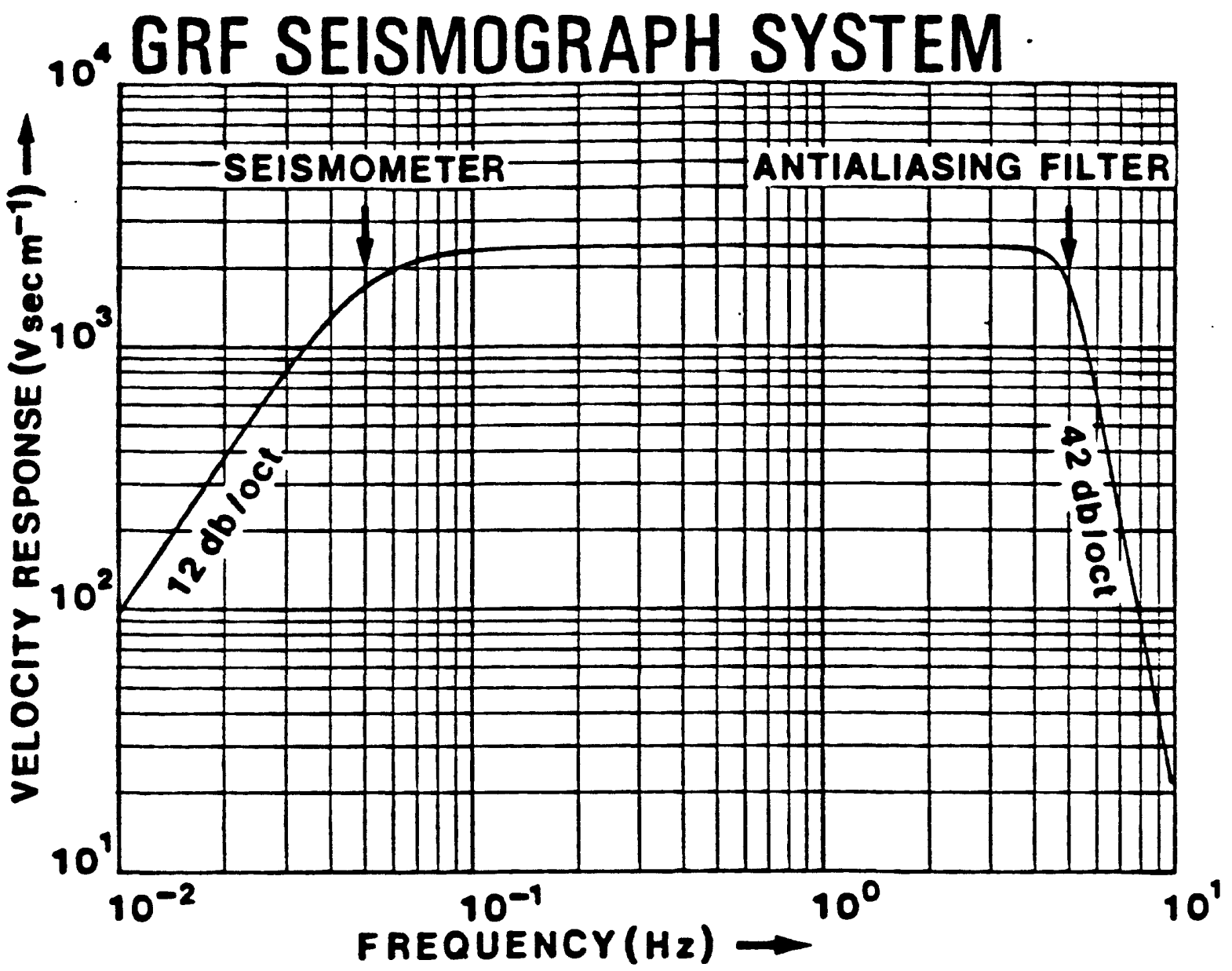

Figure 6. Ground velocity transfer function of the GRF broadband seismometer system. 


\section{MODIFICATIONS AND PROBLEMS}

A new digital-data format became effective on January 1, 1988. This format is more portable, provides more information, is expandable, and can be used both for recording field data and for distribution in the form of network-day and event tapes. A new format was introduced at this time due to the start of the Global Seismic Network (GSN), which will ultimately comprise 50 or more seismograph stations developed under the direction of the Incorporated Research Institutions for Seismology (IRIS). Installation for most of this network will not begin until 1989. However, several preliminary stations, referred to as IRIS-1 stations, started recording data in early 1988. These stations include one in Harvard, Massachusetts, and one in Pasadena, California. Three more IRIS-1 stations will be installed during the next few months in Missouri, Hawaii, and Alaska. These stations will produce long-period data at 1 sample per second (sps), broadband data at 20 sps and very long period data at 0.1 sps. The Pasadena station will also include an event-detected, low-gain, three-component, strong-motion recording system at 100 sps. All of these data are continuous and, to reduce storage media, will be distributed in a compressed data format. The addition of these five IRIS-1 stations will increase the amount of data to be processed at the Data Collection Center in Albuquerque, New Mexico, from approximately 30 megabytes per day to more than 60 megabytes per day. Therefore, all Network-Day Tapes dated January 1, 1988, or later will be recorded at a density of 6250 bpi. New software is presently under development to assist the seismic research community in accessing these data.

The new format has been discussed in detail with both data users and network operators from this country and from overseas. Their reaction has been very positive. There was a strong consensus that a universal format for recording and distributing digital seismic data would be a significant advance for the seismological community. A report explaining this format in complete detail has been assembled. Anyone wishing copies of the report please contact the Albuquerque Seismological Laboratory, Building 10002, Kirtland AFBEast, Albuquerque, New Mexico 87115.

The following entries describe current updates and/or problems associated with the various digital stations and contributing networks.

AFI: All digital data was one day (24 hours) in error from May 1 through May 13, 1987. The date on the digital data is 24 hours ahead; therefore, one day should be subtracted from the header data.

TOL: Streckeisen seismometers were installed effective October 5, 1987.

CTAO: Streckeisen seismometers were installed effective September 27, 1987.

RSNY: Seismometer orientation was in error by $17^{\circ}$ clockwise for all Network-Day Tape data distributed for this station.

ZOBO: The LPN and LPE polarities have been reversed since approximately January 20 , 1987. 
LZH: The horizontal components for both long-period and short-period data had reverse polarity from original installation date until October 24, 1987.

CDSN SP AND BB DATA: The field tapes from the CDSN stations are forwarded to Beijing where they are copied. The copies are shipped to the Albuquerque Seismological Laboratory (ASL) where the data are included in the Network-Day Tapes. During May and June 1987, a problem with the tape copy system in Beijing resulted in occasional two-minute jumps in the SP and BB data. Most of these jumps were correctable at the ASL. However, when the skips occurred at the beginning of a triggered event, it was not possible to make any correction. Therefore, for the CDSN stations listed below, it is possible for a triggered event to start two minutes late during the time period indicated.

BJI: 29 Apr - 03 Aug 1987

LZH: 24 May - 20 Jul 1987

KMI: 27 Apr - 20 Jul 1987

WMQ: 13 Apr - $18 \mathrm{Jul} 1987$

HIA: 27 Apr - 20 Jul 1987 
STATION PROBLEMS AND MODIFICATIONS

\author{
Station Date Description \\ AFI 15 May 1981 Station installed. \\ 27 April 1987 Streckeisen seismometers installed. \\ 01 May 1987 Date was 24 hours ahead. To obtain the correct date, one day should \\ thru \\ 13 May 1987 \\ ANMO 01 Sep 1974 \\ be subtracted in the tape header. \\ 09 Dec 1975 \\ Station installed. \\ 24 Jul 1978 \\ thru \\ $31 \mathrm{Jul} 1978$ \\ 23 Oct 1978 \\ 4-pole Bessel filters replaced 4-pole Butterworth anti-aliasing filters (long- \\ period signals). \\ Multiplexing errors occurred from $24 \mathrm{Jul}$ 16:45:57.0 through $31 \mathrm{Jul}$ \\ 15:57:56.0. Channel sequence is $\mathrm{N}, \mathrm{E}, \mathrm{Z}$. \\ $30 \mathrm{Jul} 1980$ Long-period sensitivities changed: $\mathrm{Z}=\mathbf{4 5 0 0}$ counts, $\mathrm{N}-\mathrm{S}=\mathbf{5 0 0 0}$ counts, \\ and $\mathrm{E}-\mathrm{W}=5500$ counts per micrometer of ground motion at a period \\ of 25 seconds.
}

13 May 1981 Clip detectors installed.

05 Apr 1983 Horizontal short-period components installed.

24 May 1983 The six second notch filter was removed, as were two single pole highpass corners on the ANMO long-period filters. Pole 1 was moved from 250 seconds to 1200 seconds, and pole 2 was moved from 670 seconds to 1200 seconds.

19 Mar 198422 Feb 1984 software installed. Calibration procedure revised.

01 Oct 1984 During the first three weeks of October 1984, a new borehole was drilled close to the existing ANMO borehole. The long-period channels at ANMO became saturated during drilling operations. Drilling hours varied between 1500 and 2300 lours UTC.

20 Feb 1985 Both short-period horizontal components were removed from the ANMO recording system to facilitate testing of a modified borehole seismometer. The SPZ component will be included with the ANMO data for the next few months.

09 Dec 1985 Polarity reversed on the LPE channel.

thru

08 Jan 1986

ANTO 01 Aug 1978

Station installed.

26 Feb 1979

The 4-pole Bessel anti-aliasing filter on the N-S component failed and was temporarily replaced with a 4-pole Butterworth filter on February 26,1979 . The Butterworth filter was replaced with a new Bessel filter on October 10, 1979. This was the N-S component only. 
03 Oct 1980

$27 \mathrm{Jul} 1984$ thru

07 Sep 1984

19 Oct 1984

thru

16 Nov 1986

BCAO

12 Jun 1979

12 Jun 1979

thru

26 Apr 1980

25 Sep 1980

Nov 1981

$29 \mathrm{Feb} 1984$

03 Mar 1984

14 Aug 1984

14 Aug 1984

14 Aug 1984

BER

10 Aug 1981

01 Sep 1984

BGIO

$10 \mathrm{Jul} 1986$

10 Jul 1986

thru

25 Jul 1986

BOCO

13 Mar 1978

Long-period sensitivities changed: $Z=4500$ counts, $N-S=5000$ counts, and $\mathrm{E}-\mathrm{W}=\mathbf{5 5 0 0}$ counts per micrometer of ground motion at a period of 25 seconds.

The time was exactly one hour fast. To obtain the correct time, one hour should be subtracted from the time listed in the tape header.

The time was exactly one hour fast from 16 Oct 07:40 through 19 Nov 1984 00:00 UTC. To obtain the correct time, one hour should be subtracted from the time listed in the record header.

Station installed.

Polarity reversals on both horizontal components.

Long-period sensitivities changed: $Z=4500$ counts, $N-S=5000$ counts, and $\mathrm{E}-\mathrm{W}=5500$ counts per micrometer of ground motion at a period of 25 seconds.

The BCAO system was damaged by lightning during November 1981 . When repairs to the system were completed, including a new borehole seismometer, it was found that the seismometer cable was damaged at the point where it connects to the seismometeer. Only the long-period vertical component was affected, and the station has been in operation since $01 \mathrm{Mar} 1982$ withhout that component. On 07 Sep 1982 the cabling connections were replaced and all components are now recording data.

The 6 sec. notch was removed, and two single-pole high-pass corners were moved from 250 and 670 seconds to 1200 seconds.

Long-period transfer functions changed by removing the six second notch filters and by moving the two single-pole high-pass corners. Pole 1 was moved from 250 seconds to 1200 seconds, and pole 2 was moved from 670 seconds to 1200 seconds.

22 Feb 1984 software installed. Calibration procedure revised.

Horizontal short-period components installed.

Clip detectors installed.

Station installed.

Station closed. The digital recording system moved to Kingsbay, Svalbard (KBS).

Station installed.

Longitude incorrectly listed as 35.08 West instead of East.

Station installed.

24 Oct 1978

thru

28 Oct 1978

Multiplexing errors occurred from 24 Oct 13:48:16.0 through 28 Oct $00: 45: 56.0$. Channel sequence is $\mathrm{N}, \mathrm{E}, \mathrm{Z}$. 
thru

07 Dec 1978

08 Mar 1979

\section{CHTO}

01 Jul 1977

04 Feb 1979

06 Jul 1979

10 Dec 1980

May 1983

22 May 1983

thru

7 Jan 1984

21 May 1984

24 May 1984

24 May 1984

21 Sep 1984

$\mathrm{COL}$

CTAO

09 Oct 1976

01 Jan 1980

thru

01 May 1981

29 Dec 1980

03 Jun 1983

27 Sep 1987

GRFO

01 Oct 1978
21 Nov 1978

Multiplexing errors occurred from 21 Nov 18:33:03.0 through 07 Dec 15:34:06.0. Channel sequence is $E, Z, N$.

Long-period sensitivities changed: $\mathrm{Z}=\mathbf{4 5 0 0}$ counts, $\mathrm{N}-\mathrm{S}=\mathbf{5 0 0 0}$ counts, and $\mathrm{E}-\mathrm{W}=5500$ counts per micrometer of ground motion at a period of 25 seconds.

Station installed.

Single-pole low-pass sections cornered at $16 \mathrm{~Hz}$ in short-period channels removed.

4-pole Bessel filters replaced 4-pole Butterworth anti-aliasing filters (longperiod signals).

Long-period sensitivities changed: $Z=4500$ counts, N-S $=5000$ counts, and $\mathrm{E}-\mathrm{W}=\mathbf{5 5 0 0}$ counts per micrometer of ground motion at a period of 25 seconds.

After being inoperative for more than 1 year, CHTO came on line in early May 1983 after the installation of a new power system.

Polarity reversed on all long- and short-period channels.

2-22-84 software installed. Calibration procedure revised.

Long-period transfer functions changed by removing the six second notch filters and by moving the two single-pole high-pass corners. Pole 1 was moved from 250 seconds to 1200 seconds, and pole 2 was moved from 670 seconds to 1200 seconds.

Horizontal short-period components installed.

Clip detectors installed.

Station installed.

Streckeisen seismometers installed.

Station installed.

A pole was not included in the original long-period transfer function listings on the network-day tapes. The pole which should be added is $(-0.159 \mathrm{E}+00,-0.594 \mathrm{E}+00)$.

Long-period sensitivities changed: $Z=9000$ counts, $N-S=10000$ counts, and $\mathrm{E}-\mathrm{W}=11000$ counts per micrometer of ground motion at a period of 25 seconds.

Short-period sensitivity was reduced from $10^{5}$ to $10^{6}$ counts per micrometer at one second.

Streckeisen seismometers installed. 
03 Nov 1978

thru

11 Dec 1978

19 Jun 1979

08 Mar 1980

thru

03 Apr 1980

18 Oct 1980

GUMO

01 Dec 1975

27 Apr 1976

19 Dec 1979

29 Jul 1980

08 Jan 1985

thru

11 Apr 1985

15 Jan 1985

$15 \mathrm{~J}$ an 1985

JAS

JAS1

01 Oct 1980

26 Jun 1984

$03 \mathrm{Jul} 1984$

27 Jul 1984

06 Nov 1986

KAAO

10 May 1977

12 Sep 1978

thru

13 Sep 1978

08 Dec 1978

thru

10 Dec 1978
Vertical component recorded simultaneously on channels 1 and 2 from 3 Nov 1978 at 05:41 through $11 \mathrm{Dec} 1978$ at 14:53. Channel sequence is $\mathrm{Z}, \mathrm{Z}, \mathrm{E}$.

Single-pole low-pass sections cornered at $16 \mathrm{~Hz}$ in short-period channels removed.

Long-period channels multiplexed incorrectly. Channel sequence is $\mathrm{E}$, $\mathrm{Z}, \mathrm{N}$.

Long-period sensitivities changed: $Z=4500$ counts, $N-S=5000$ counts, and $\mathrm{E}-\mathrm{W}=5500$ counts per micrometer of ground motion at a period of 25 seconds.

Station installed.

Short-period sensitivity reduced from $2,000,000$ to 2,000 digital counts per micrometer of ground motion at a period of 1 second. The $R E$. SPONSE TO EARTH DISPLACEMENT table located in the shortperiod data log was modified beginning on Day 326, 1981. Changes in the values for the relative amplitudes average $2 \%-3 \%$. Changes in the phase angle values are more significant, averaging between $5 \%-10 \%$.

4-pole Bessel filters replaced 4-pole Butterworth anti-aliasing filters (longperiod signals).

Long-period sensitivities changed: $Z=4500$ counts, $N-S=5000$ counts, and $\mathrm{E}-\mathrm{W}=5500$ counts per micrometer of ground motion at a period of 25 seconds.

Station closed on 8 Jan 1985 for replacement of the Model KS36000 borehole seismometer with the Streckeisen Model STS-I surface seismometer. New transfer functions and sensitivites are included in station and data logs. GUMO became fully operational on 11 Apr 1985 .

22 Feb 1984 software installed. Calibration procedure revised.

Clip detectors installed.

Station installed.

Station closed. Seismograph system moved to a new location. The new station code is JAS1.

Station installed.

Digital data included on network-day tapes.

Station closed. Seismograph system was moved to a new location. The new station code is CMB.

Station installed.

Multiplexing errors occurred from 12 Sep 18:32:15.0 through 13 Sep $07: 33: 28.0$. Channel sequence is $N, E, Z$.

Multiplexing errors occurred from 08 Dec 06:02:59.0 through 10 Dec 06:10:28.0. Channel sequence is $\mathrm{N}, \mathrm{E}, \mathrm{Z}$. 
11 Dec 1978

thru

24 Dec 1978

01 Jan 1980 thru

01 May 1981

20 Jan 1981

thru

17 Feb 1982

$30 \mathrm{Jul} 1982$

KEV

14 Oct 1981

15 Mar 1982

thru

26 Mar 1982

12 Mar 1987

KONO

01 Sep 1978

01 Jan 1980

thru

01 May 1981

12 Oct 1980

30 May 1983

01 Oct 1980

06 Apr 1981

thru

18 Jan 1982

MAIO $\quad 14$ Oct 1975

24 Nov 1977

thru

27 Nov 1977

11 Oct 1978

MAJO

15 Jun 1977

20 Nov 1977

thru

21 Nov 1977

01 Jan 1980

thru

01 May 1981
Time is 330 seconds fast from 11 Dec 1978 through 24 Dec 1978 at 0:700.

A pole was not included in the original long-period transfer function listings on the network-day tapes. The pole which should be added is $(-0.159 \mathrm{E}+00,-0.594 \mathrm{E}+00)$.

The EW and $\mathrm{Z}$ components were switched.

Last data received. Station closed.

Station installed.

The network-day tape data starting 15 Mar 1982 through 26 Mar 1982 at 06:00 UTC is approximately 15 to 20 minutes fast.

Streckeisen seismometers installed.

Station installed.

A pole was not included in the original long-period transfer function listings on the network-day tapes. The pole which should be added is $(-0.159 E+00,-0.594 E+00)$.

Long-period sensitivities changed: $Z=9000$ counts, $N-S=10000$ counts, and $\mathrm{E}-\mathrm{W}=11000$ counts per micrometer of ground motion at a period of 25 seconds.

Short-period sensitivity was reduced from $10^{5}$ to $10^{6}$ counts per micrometer at one second. Calibration procedure for SRO/ASRO was revised.

Station installed.

All digital short-period vertical component data during this time frame has reversed polarity.

First data distributed on Station Tape.

Multiplexing errors occurred from 24 Nov 7:35:30.0 through 27 Nov 5:20:59.0. Channel sequence is $N, E, Z$.

Last data received. Station closed.

Station installed.

Multiplexing errors occurred from 20 Nov 05:39:24.0 through 21 Nov 00:54:23.0. Channel sequence is $N, E, Z$.

A pole was not included in the original long-period transfer function listings on the network-day tapes. The pole which should be added is $(-0.159 \mathrm{E}+00,-0.594 \mathrm{E}+00)$. 
03 Aug 1980

03 Mar 1983

NWAO 01 Apr 1976

20 Mar 1977 thru

21 Mar 1977

01 Aug 1977 thru

3 Aug 1977

01 Dec 1977

05 May 1978

thru

6 May 1978

13 Jun 1978

thru

14 Jun 1978

30 Dec 1978

01 Aug 1979 thru

21 Aug 1979

24 Dec 1980

21 Jan 1982 thru

01 Feb 1982

RSCP

12 Dec 1982

13 May 1985

01 Apr 1985

22 Oct 1986

RSNT

12 Dec 1982

15 Feb 1983

thru

01 Mar 1984

01 Apr 1985

22 Oct 1986
Long-period sensitivities changed: $Z=9000$ counts, $N-S=10000$ counts, and $\mathrm{E}-\mathrm{W}=11000$ counts per micrometer of ground motion at a period of 25 seconds.

Short-period sensitivity was reduced from $10^{5}$ to $10^{6}$ counts per micrometer at one second.

Station installed.

Multiplexing errors occurred from 20 Mar 17:25:27.0 through 21 Mar 03:00:57.0. Channel sequence is $\mathrm{N}, \mathrm{E}, \mathrm{Z}$.

Multiplexing errors occurred from 1 Aug 03:23:46.0 through 3 Aug 23:49:31.0. Channel sequence is $E, Z, N$.

Single-pole low-pass sections cornered at $16 \mathrm{~Hz}$ in short-period channels were removed.

Multiplexing errors occurred from 5 May 06:30:00.0 through 6 May 07:38:59.0. Channel sequence is $E, Z, N$.

Multiplexing errors occurred from 13 Jun 07:04:14.0 through 14 Jun 04:29:30.0. Channel sequence is $E, Z, N$.

4-pole Bessel filters replaced 4-pole Butterworth anti-aliasing filters (longperiod signals).

Long-period channels multiplexed incorrectly. Channel sequence is $\mathrm{N}$, E, Z.

Long-period sensitivities changed: $Z=4500$ counts, $N-S=5000$ counts, and $\mathrm{E}-\mathrm{W}=5500$ counts per micrometer of ground motion at a period of 25 seconds.

The network-day tape data starting 21 Jan 16:23 UTC through 01 Feb 00:31 UTC is 7 hours 52 minutes slow.

Data included on Network-Day Tapes. (V1N2)

Station has been modified to make the transfer functions and sensitivities identical to other RSTN stations.

The short-period horizontal components have been switched from the KS36000 to the S-750 borehole seismometer.

RSTN network temporarily closed.

Data included on Network-Day Tapes.

The short-period vertical transfer function included four incorrect poles plus the wrong sign for $\mathrm{A} 0$. The incorect poles were P03, P04, P05 and P06.

The short-period horizontal components have been switched from the KS 36000 to the S-750 borehole seismometer.

RSTN network temporarily closed. 
Data included on Network-Day Tapes.

15 Feb 1983

thru

$08 \mathrm{Jul} 1984$

01 Apr 1985

22 Oct 1986

RSNY

12 Dec 1982

12 Dec 1982 thru

02 Mar 1984

15 Feb 1983

thru

01 Mar 1984

01 Apr 1985

12 Dec 1982 thru

22 Oct 1986

22 Oct 1986

RSON

$01 \mathrm{Jul} 1978$

12 Dec 1982 thru

02 Mar 1984

15 Feb 1983 thru

01 Mar 1984

01 Apr 1985

22 Oct 1986

SHIO
The short-period vertical transfer function included four incorrect poles plus the wrong sign for $\mathrm{A} 0$. The incorect poles were $\mathrm{P} 03, \mathrm{P} 04, \mathrm{P} 05$ and P06.

The short-period horizontal components have been switched from the $\mathrm{KS} 36000$ to the S-750 borehole seismometer.

RSTN network temporarily closed.

Data included on Network-Day Tapes.

The short-period horizontal transfer functions have listed an incorrect A0 constant plus a missing zero (Z01).

The short-period vertical transfer function included four incorrect poles plus the wrong sign for A0. The incorect poles were P03, P04, P05 and P06.

The short-period horizontal components have been switched from the KS36000 to the S-750 borehole seismometer.

Seismometer orientation was in error $17^{\circ}$ clockwise.

RSTN network temporarily closed.

Station installed.

The short-period horizontal transfer functions have listed an incorrect A0 constant plus a missing zero (Z01).

The short-period vertical transfer function included four incorrect poles plus the wrong sign for $\mathrm{A} 0$. The incorect poles were P03, P04, P05 and P06.

The short-period horizontal components have been switched from the KS36000 to the S-750 borehole seismometer.

RSTN network temporarily closed.

$01 \mathrm{Jul} 1978 \quad$ Station installed.

01 Aug 1978 thru

26 Sep 1978

14 Sep 1978 thru

21 Sep 1978

14 Sep 1978 thru

21 Sep 1978

25 Mar 1980

thru

Polarity reversals on both horizontal components.

Multiplexing errors occurred from 14 Sep 06:31:06.0 through 21 Sep 09:39:35.0. Channel sequence is $E, Z, N$.

Long-period channels multiplexed incorrectly. Channel sequence is $\mathrm{E}$, $\mathrm{Z}, \mathrm{N}$.

Long-period channels multiplexed incorrectly. Channel sequence is $\mathrm{E}$, Z, N. 
30 Nov 1980

19 Feb 1984

31 Mar 1985

31 Mar 1985

31 Mar 1985

27 May 1985

thru

18 Aug 1985

03 Mar 1986

SLR

SNZO

10 Nov 1978

10 Nov 1978

07 Jan 1981

TATO

13 May 1976

13 May 1976

16 Sep 1977

thru

17 Sep 1977
Long-period sensitivities changed: $Z=\mathbf{4 5 0 0}$ counts, $\mathrm{N}-\mathrm{S}=\mathbf{5 0 0 0}$ counts, and $\mathrm{E}-\mathrm{W}=5500$ counts per micrometer of ground motion at a period of 25 seconds.

Long-period transfer functions changed by removing the six second notch filters and by moving the two single-pole high-pass corners. Pole 1 was moved from 250 seconds to 1200 seconds, and pole 2 was moved from 670 seconds to 1200 seconds.

22 Feb 1984 software installed. Calibration procedure revised.

Horizontal short-period components installed.

Clip detectors installed.

Station tapes arrived at the Albuquerque Seismological Laboratory after the network-day tapes had been written. Station day tapes have been produced containing data from SHIO only in day tape format for this period.

Last data received. Station closed.

Station installed.

All data is in error by exactly 24 hours starting at $14 \mathrm{Feb}$ at 04:00 until $1 \mathrm{May}$ at 00:00 UTC. The data is one day late. After a power outage on $14 \mathrm{Feb} 1986$ the clock was incorrectly reset to $15 \mathrm{Feb} 1986$.

Station installed.

Short-period sensitivity reduced from $2,000,000$ to 2,000 digital counts per micrometer of ground motion at a period of 1 second. The $R E$ SPONSE TO EARTH DISPLACEMENT table located in the shortperiod data log was modified beginning on Day 326,1981 . Changes in the values for the relative amplitudes average $2 \%-3 \%$. Changes in the phase angle values are more significant, averaging between 5\%-10\%.

4-pole Bessel filters replaced 4-pole Butterworth anti-aliasing filters (longperiod signals).

Single-pole low-pass sections cornered at $16 \mathrm{~Hz}$ in short-period channels removed.

Long-period sensitivities changed: $Z=\mathbf{4 5 0 0}$ counts, $\mathrm{N}-\mathrm{S}=\mathbf{5 0 0 0}$ counts, and $\mathrm{E}-\mathrm{W}=5500$ counts per micrometer of ground motion at a period of 25 seconds.

Station installed.

Short-period sensitivity reduced from $2,000,000$ to 2,000 digital counts per micrometer of ground motion at a period of 1 second. The $R E$ SPONSE TO EARTH DISPLACEMENT table located in the shortperiod data log was modified beginning on Day 326, 1981. Changes in the values for the relative amplitudes average $2 \%-3 \%$. Changes in the phase angle values are more significant, averaging between $5 \%-10 \%$.

Multiplexing errors occurred from 16 Sep 03:12:04.0 through 17 Sep 04:02:34.0. Channel sequence is $N, E, Z$. 
06 Sep 1978

thru

07 Sep 1978

30 Nov 1978

25 Jan 1979

14 Sep 1979

thru

26 Aug 1980

22 Aug 1980

TOL

03 Nov 1981

ZOBO
05 Oct 1987

Multiplexing errors occurred from 06 Sep 03:24:17.0 through 07 Sep 05:37:16.0. Channel sequence is $N, E, Z$.

Single-pole low-pass sections cornered at $16 \mathrm{~Hz}$ in short-period channels removed.

4-pole Bessel filters replaced 4-pole Butterworth anti-aliasing filters (longperiod signals).

Polarity reversals on both horizontal components.

Long-period sensitivities changed: $Z=4500$ counts, $N-S=5000$ counts, and $\mathrm{E}-\mathrm{W}=5500$ counts per micrometer of ground motion at a period of 25 seconds.

Station installed.

Streckeisen seismometers installed.

10 Sep 1976 Station installed.

27 Dec 1977 thru

28 Feb 1978

10 Feb 1978 thru

11 Feb 1978

06 Jun 1978 thru

14 Jun 1978

18 Sep 1978

01 Jan 1980 thru

01 May 1981

11 May 1982
The E-W channel was down. The N-S and E-W channels were temporarily switched from 10 Feb 1978 through 14 Feb 1978.

Multiplexing errors occurred from 10 Feb 16:41:06.0 through 11 Feb 12:51:05.0. Channel sequence is $\mathrm{N}, \mathrm{E}, \mathrm{Z}$.

Multiplexing errors occurred from 06 Jun 18:48:02.0 through 14 Jun 14:48:33.0. Channel sequence is $N, E, Z$.

During recalibration of the LPN and LPE components, incorrect motor constants were used, resulting in a sensitivity setting of 10000 digital counts per 1.4 microns of ground motion at a period of 25 seconds. LPN and LPE calibrations since that date are for an equivalent ground motion of 1.4 microns. The actual calibration for 1 micron of ground motion is approximately 7150 digital counts. The station $\log$ in the network-day tapes contained the following statement in the comment section: 'Long-period horizontal calibration values should be increased by 27\%'. This statement should read: 'Long-period horizontal calibration values should be divided by 1.4 '. The log comments were corrected on 10 Jun 1981. The average calibration values on the network-day tapes for the long-period horizontal components were changed on 30 Jun 1981 to their correct values (approximately 7150 counts).

A pole was not included in the original long-period transfer function listings on the network-day tapes. The pole which should be added is $(-0.159 \mathrm{E}+00,-0.594 \mathrm{E}+00)$.

The station was recalibrated, and motor constants corrected. Also, the sensitivities were adjusted to coincide with those at other ASRO stations, which are $Z=9000, \mathrm{~N}-\mathrm{S}=10000$, and $\mathrm{E}-\mathrm{W}=11000$ digital counts per micrometer of ground motion at a period of 25 seconds. 
11 Aug 1983 During a maintenance visit, the long-period sensitivities for all channels were incorrectly adjusted. The long- period sensitivities are LPZ = $10,900, \mathrm{LPN}=9,900, \mathrm{LPE}=10,100$ digital counts per micron of ground motion at a period of 25 seconds.

11 May 1984

22 Feb 1984 Software installed. Calibration procedure revised.

02 Jan 1987 Polarity reversed on LPN and LPE components.

$\mathrm{BJI}$

Oct 1986

Data included on Network-Day Tape.

29 Apr 1987

thru

03 Aug 1987

Due to a problem with the Tape Copy System in Beijing, events triggered on the short-period and broadband records may start 2 minutes late.

HIA

Oct 1986

Data included on Network-Day Tape.

27 Apr 1987 Due to a problem with the Tape Copy System in Beijing, events trigthru $20 \mathrm{Jul} 1987$ gered on the short-period and broadband records may start 2 minutes late.

KMI

Oct 1986

Data included on Network-Day Tape.

27 Apr 1987 thru $20 \mathrm{Jul} 1987$

LZH Oct 1986

Oct 1986

thru

24 Oct 1987

24 May 1987

thru

$20 \mathrm{Jul} 1987$

WMQ Oct 1986

13 Apr 1987

thru

18 Jul 1987

Due to a problem with the Tape Copy System in Beijing, events triggered on the short-period and broadband records may start 2 minutes late.

Due to a problem with the Tape Copy System in Beijing, events triggered on the short-period and broadband records may start 2 minutes late.

Data included on Network-Day Tape.

Polarity reversals on long- and short-period horizontal components.

Data included on Network-Day Tape.

Due to a problem with the Tape Copy System in Beijing, events triggered on the short-period and broadband records may start 2 minutes late. 


\section{APPENDIX A}

NETWORK-DAY TAPE DOWNTIME, 1987 

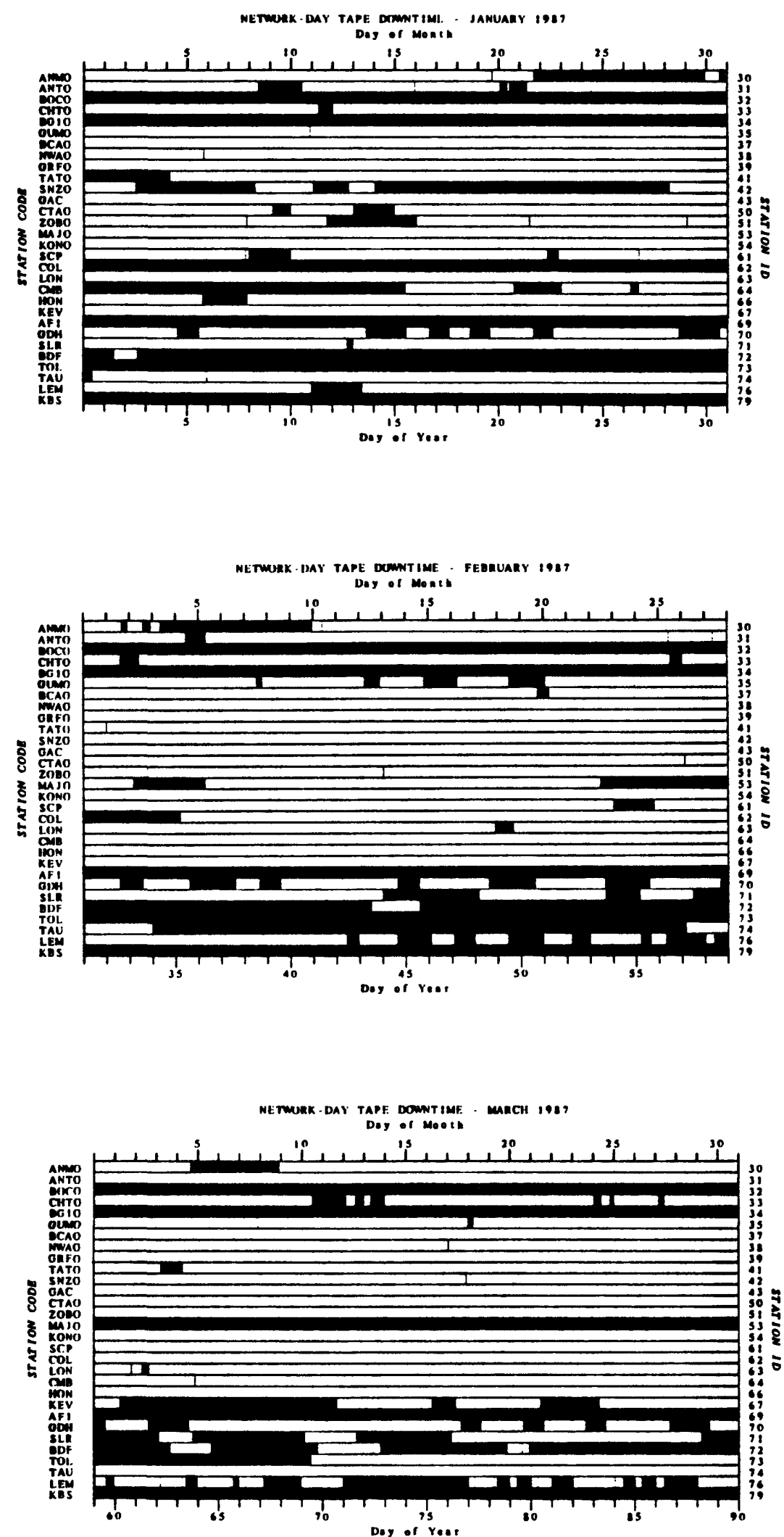

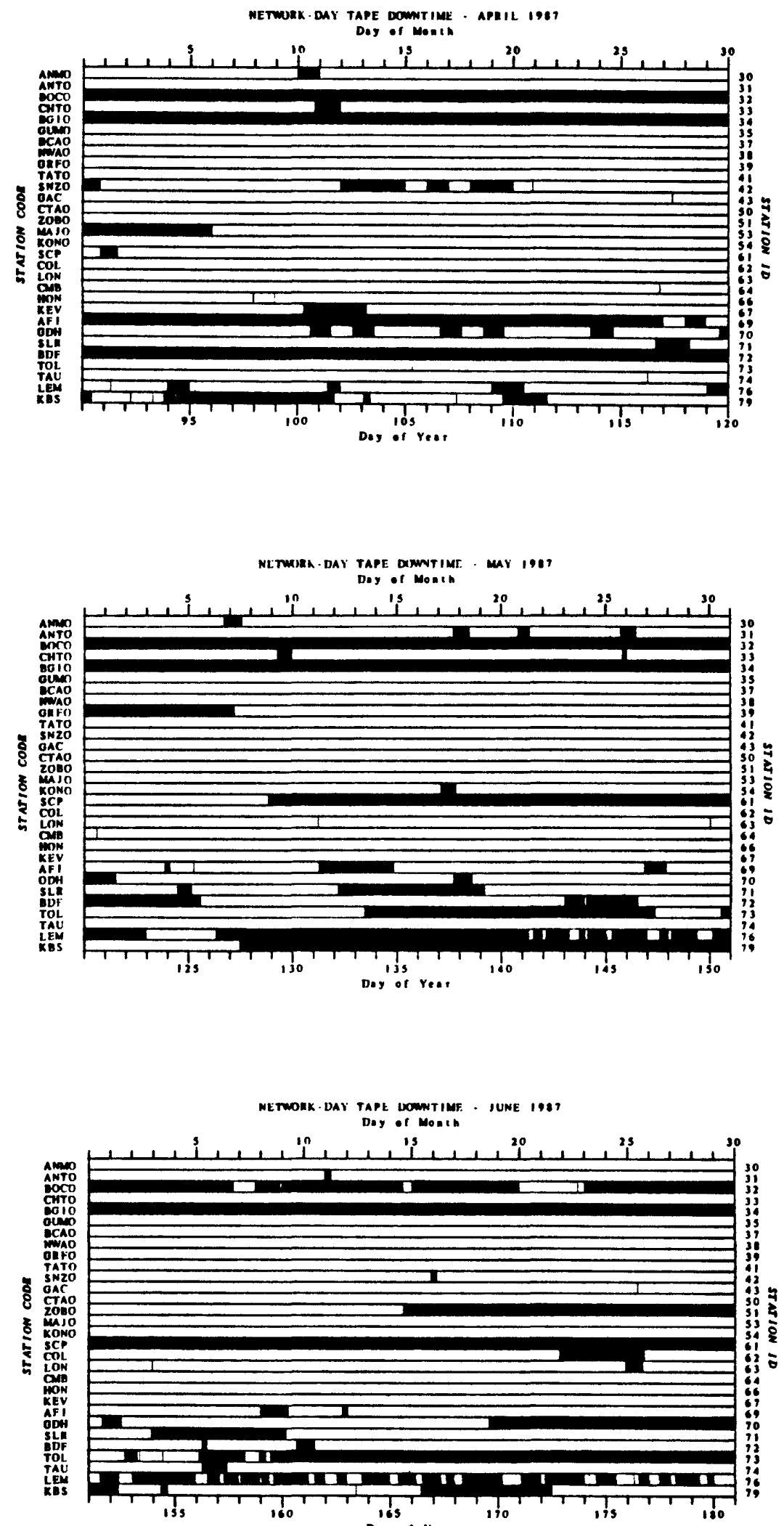

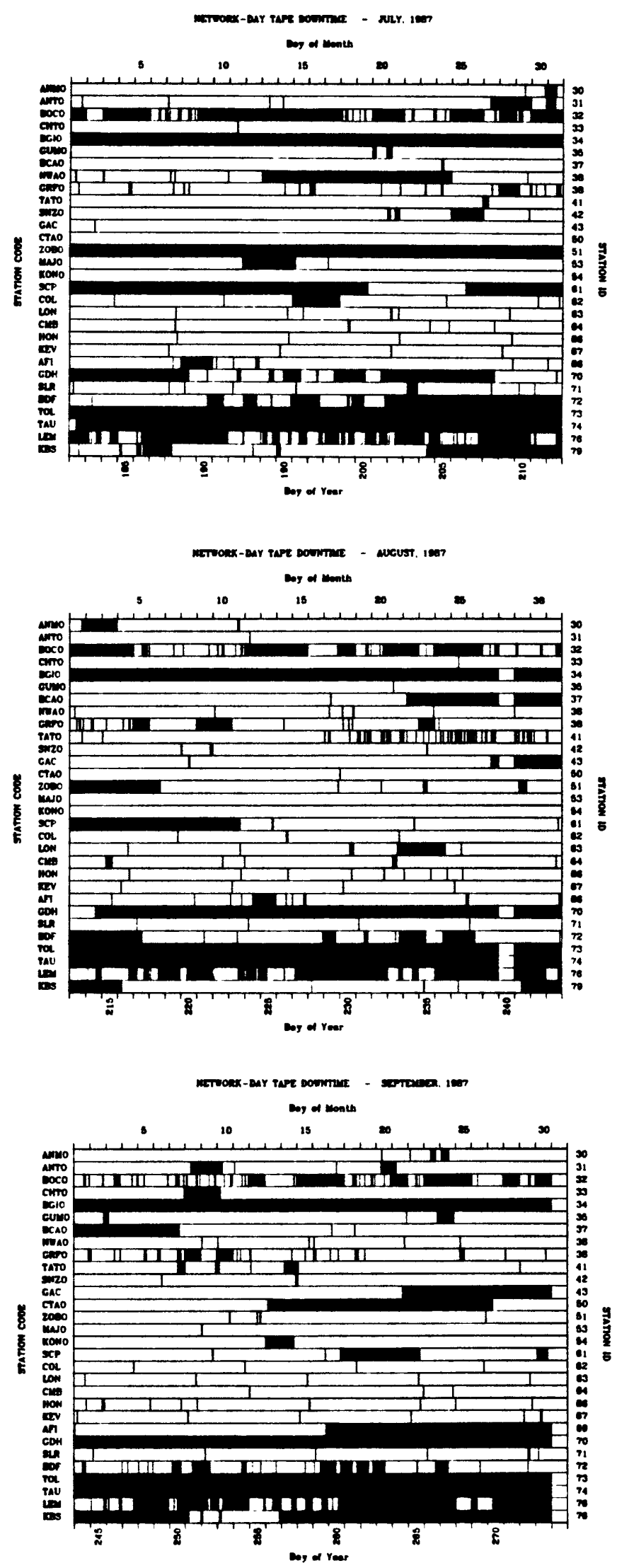

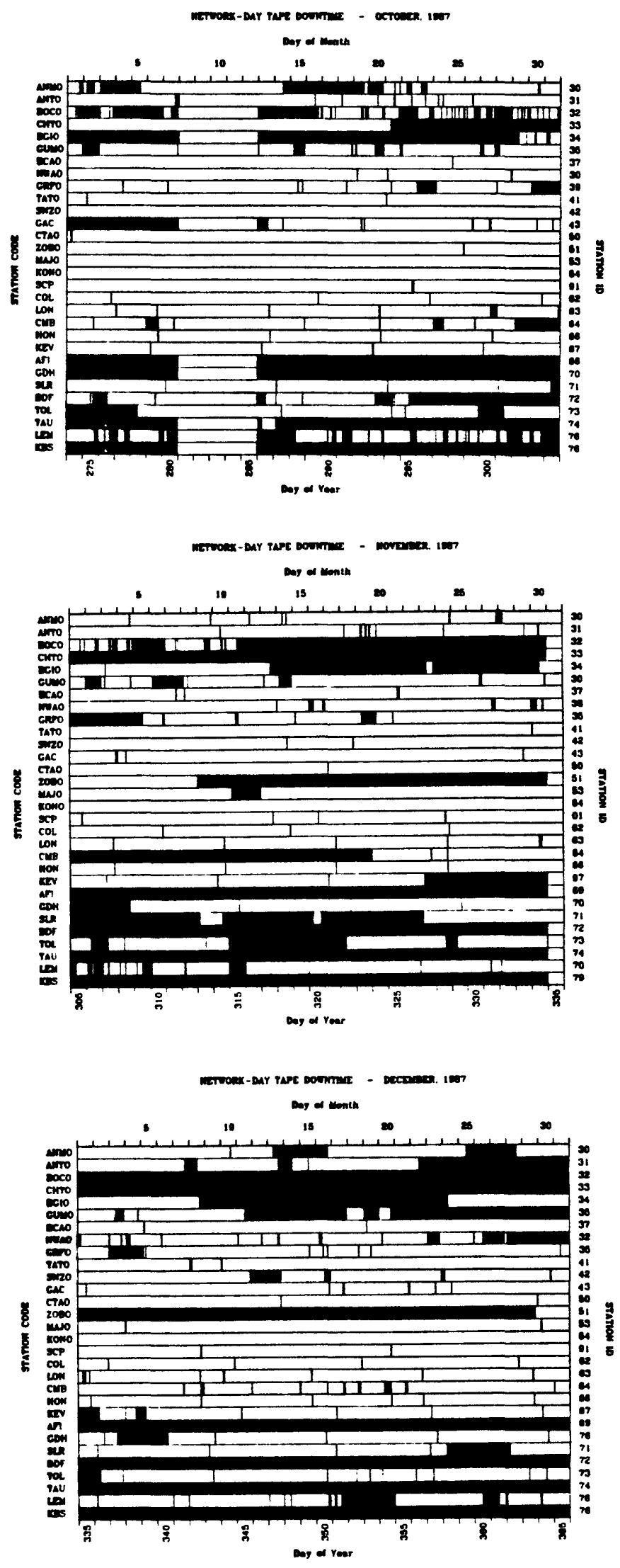
APPENDIX B

SIGNIFICANT EARTHQUAKES OF THE WORLD, 1987 
Eorthquokes of mognitude 6.5 or greater or ones that coused fatalities, injuries or substantiol domage. BRK--Berkeley. PAS--Posodena. FIR--Florence, l toly. FUR--Fuerstenteldbruck, FRG. GRF--Groefenberg, FRG. KBA--Borroge Koelnbrein, Austria. KRA--Krokow. Poland. LDG-Loborotaire de Detection et de Geaphysique, France. PMR-Polmer, Alasko. Riv--Riverview, Austrolio. ROM-Rome, ltoly. SLM--St. Louis. Missouri. TRI--Trieste, Itoly. TTG-Titograd, Yugoslovio. VKA--Vienno-Kobenzl, Austrio.

DATE ORIGIN TIME UTC

JAN 03
DEPTH

$\begin{array}{lr}\text { MAGNITUDES SD NO. } \\ \text { GS } & \text { STA } \\ \text { MB MSZ } & \text { USED }\end{array}$

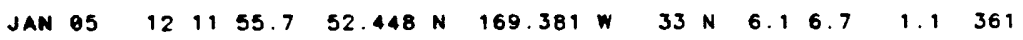

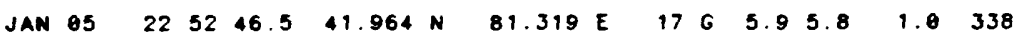

JAN 09

JAN 69

JAN 11

JAN 14
$0801 \quad 35.9 \quad 19.469 \mathrm{~S} \quad 176.538 \mathrm{~W}$

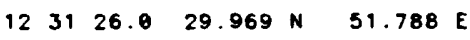

110348

$$
42.565 \mathrm{~N} \quad 142.850 \mathrm{E}
$$

$33 N 5.96 .6$

$10 \cdot 4.94 .1$

$102 \mathrm{G} 6.5$

$\begin{array}{llllllllllll}\text { JAN } 22 & 05 & 10 & 51.1 & 43.515 \mathrm{~N} & 10.154 \mathrm{E} & 22 & & & 1.1 & 62 \\ \text { JAN } 24 & 080921.3 & 41.529 \mathrm{~N} & 79.318 \mathrm{E} & 290 & 5.95 .9 & 1.2 & 254\end{array}$

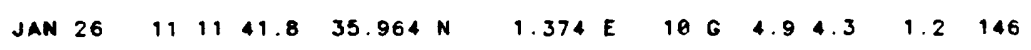

JAN $30 \quad 22 \quad 2942.0 \quad 60.063 \mathrm{~s} \quad 26.916 \% \quad 48006.27 .0 \quad 1.4 \quad 172$

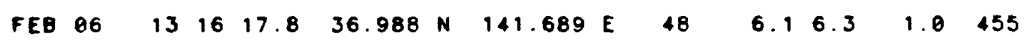

$\begin{array}{lllllllllll}\text { FEB } & 98 & 18 & 33 & 58.3 & 6.688 & \mathrm{~S} & 147.689 & \text { E } & 55\end{array}$

FEB 11

$\begin{array}{llllll}07 & 56 & 12.9 & 15.834 \mathrm{~S} \quad 167.355 \mathrm{E}\end{array}$

FEO 1

FEB 17

$07 \quad 18 \quad 29.8$

$0.676 \mathrm{~N} 126.167 \mathrm{E}$

$\begin{array}{lllllll}06 & 16 & 12.1 & 32.793 \mathrm{~S} & 179.304 \mathrm{w}\end{array}$

$083154.453 .470 \mathrm{~N} 167.291 \mathrm{~W}$ $\begin{array}{lllll}10 & 6 & 5.9 & 6.6 & 1.2 \quad 294\end{array}$ $\begin{array}{llllll}10 & G & 6.2 & 6.7 & 1.1 & 428\end{array}$

REGION, CONTRIBUTED MAGNITUDES AND COMMENTS

VANUATU ISLANDS. Ms 6.7 (BRK), 6.6 (PAS). Complex rupture. Depth from broodbond displocement seismogroms. bosed on dominont second event.

FOX ISLANDS, ALEUTIAN ISLANDS. MS 6.5 (BRK), 6.3 (PAS). Complex rupture. Felt (V) ot Unolosko ond (ili) ot Folse Poss. Also felt strongly at Nikolski.

SOUTHERN XINJIANG, CHINA. Severol people injured and domoge in the Boicheng oreo. Felt in the

Aksu-kugo-Wushi orea. Depth from broodband displocement se i smogroms.

HONSHU, JAPAN. mb 6.8 (PAS), 6.6 (BRK). Minor domoge (V JMA) in the Morioko-ofunoto area. Felt (IV JMA) ot Hochinohe, Ishinomaki, Miyako, Sokolo ond Sendai) (11) JMA) in the Tokyo-Yokohomo oreo ond os for north os Kushiro. Hokkoido. Two events obout $3 \mathrm{sec}$ oport. Depth from broodbond displacement seismogroms, bosed on the first event.

FIJI ISLANDS REGION. MS 6.8 (BRK), 6.7 (PAS).

SOUTHERN IRAN. Three hundred houses domoged in the Doshmon ziori oreo.

HOKKAIDO, JAPAN REGION. Mb 6.6 (BRK). Six peOple injured. Felt (V JMA) ot Kushiro: (IV JMA) ot Hiroo, Nemura, Obihira and Urokowa. Also felt (IV JMA) ot Hochinahe and Mariako. Honshu. Felt (II JMA) in the Tokyo-Yokohomo oreo, Hanshu. Depth from broodbond displocement seismogroms.

CENTRAL ITALY. ML 4.2 (KBA), 3.9 (LDG). MD 4.1 (FIR). Two people died of heort oltocks. Felt in the Livarno areo.

KIRGHIZ-XINJIANG BORDER REGION. At leost 417 houses damoged in the Wushi oreo. Chino. Felt (IV) in the Almo ata-Przhevalsk areo and $(i i l)$ in the Frunze-Noryn orea. USSR.

ALGERIA. One person killed, 7 injured and 629 homes domoged in the Mahommodio orea. Felt at Oued Foddo and Tissemsilt.

SOUTH SANDWICH ISLANDS REGION. MS 6.9 (BRK), 6.8 (PAS).

NEAR EAST COAST OF HONSHU, JAPAN. MS 6.5 (PAS), 6.3 (BRK). Felt ( $V$ JMA) ot Onohomo ond (IV JMA) ot Mito, Sendoi. Tokya. Utsunomiyo and Yokohomo. Fell from Hikane and Wojimo, Honshu ta Kushiro. Hakkaido. Also felt on Oshimo and Hochijo-jimo. Local Isunomi recorded with maximum wave heights $12 \mathrm{~cm}$ ot Onahoma; $8 \mathrm{~cm}$ ot Ishinomaki: $7 \mathrm{~cm}$ ot ofunoto. Two events obout 4 seconos opart, observed on broodbond displacement seismogroms.

EAST PAPUA NEW GUINEA REGION. MS 7.6 (BRK), 7.0 (PAS). Three people killed by 0 landslide ond some domoge (Vi) on the Huon Peninsulo. Several hundred people homeless and maderate damage ( $V I I$ ), landslides and ground cracks on Umboi island. Liquefoction occurred in some sonds on Molai island. Felt (VI) in the Cope Glaucester orea. New Britain. Felt $(111)$ os far away os Wewak and Port Maresby. New Guineo and Robaul. New Britain. Multiple event, observed on broodbond displacement seismograms

VANUATU ISLANDS. Ms 6.6 (BRK), 6.4 (PAS). Depth from broodbond displocement seismogroms.

MOlucca passage. Ms 6.4 (PAS). Felt on Ternote and of Monodo. Sulowesi.

SOUTH OF KERMADEC ISLANDS. MS 6.5 (BRK). 6.4 (PAS).

FOX ISLANDS, ALEUTIAN ISLANDS. MS 6.8 (BRK), 6.5 (PAS) Minar domage of Dutch Harbor ond Unolosko. Felt (V) ot Akuton. (111) ot Cold Boy ond Folse Poss and (11) at Sondpoint. 
ORIGIN TIME UTC

HR MN SEC
GEOGRAPHIC COORDINATES LAT
DEPTH

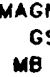
NO. USED

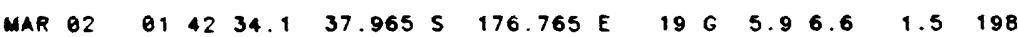

0. 1

SOUTHERN ITALY. MD 4.1 (FIR), 3.B (ROM). One person injured sightiy ond minor domoge in the Genzano di Roma-velletri orea. Felt ot Rome. extensive domoge $(x)$ in the Edgecumbe-kowerou-whakotone orea. Felt throughout much of North islond. Londslides and sondblows occurred. A southwest trending toult scorp $6 \mathrm{~km}$. Iong hod extension openings of up to $1 \mathrm{~m}$. ond os much os $1.5 \mathrm{~m}$. Of downthrow on the northwest side. Peok ground occelerotion of $0.33 \mathrm{~g}$. wos recorded within $15 \mathrm{~km}$. of the epicenter. Depth from broodband displocement se ismogroms.

NEAR COAST OF NORTHERN CHILE. MS 7.2 (BRK), 7.0 (PAS), Antofagasto oreo. Felt (VI) of Chuquicomota: (V) in the Tol tol-Toconoo-Colomo oreo: (IV) ot Arico; (III) ot vollenar. Felt (11) ot arequipo. Peru. Also telt ot lo Paz. Bolivia. Locol tsunomi generoted with maximum wove heights $22 \mathrm{~cm}$. ot Caldera, $20 \mathrm{~cm}$. ot Coquimbo, $14 \mathrm{~cm}$. ot volporoiso ond $18 \mathrm{~cm}$. at Arico. Depth $\mathrm{from}$ broodbond displocement seismogroms.

COLOMBIA-ECUADOR BORDER REGION. MS 6.2 (BRK). ONE 010 building collopsed in Ouito. Ecuodor. Felt throughout northern Ecuodor. centrol ond southwestern Colombio. and northern Peru. Depth from broodbond displocement se i smogroms.

COLOMBIA-ECUADOR BORDER REGION. MS 7.0 (BRK), 6.7 (PAS). Approximately 1,000 peOple killed, 4,000 missing, 20,000 homeles, extensive damoge, londslides ond ground crocks in Nopo Province and in the Quito-tulcan oreo. Ecuodor. About $27 \mathrm{~km}$. Of the oil pipeline in Ecuodor, between Logo Agrio and Boloo, were destroyed or bodly damoged. Landslides occurred in the Pasta-Mocao oreo, Colombio. Felt (IV) ot lquitos. Peru. Felt strongly in mony ports of Ecuodor and southwestern Colombia. Also felt in centrol Colombia ond northern Peru.

POLAND. ML 2.6 (KRA). Three people killed and three injured in the Slosk Mine ot Rudo Sloska.

KYUSHU, JAPAN. WS 6.7 (BRK), 6.6 (PAS). One person killed; olso one person died from o heort ottock ond five people were injured. Domoge (V JMA) ond londslides in the Miyozoki oreo. Felt (IV JMA) in the Kumomo to-Nobeoko-Oito-Sogo oreo; (111 JMA) in the Fukuoko-kogoshimo oreo ond on southwestern Shikoku. Felt (I JMA) from Noze, Ryukyu Islands to Mito, Honshu. Seven $\mathrm{cm}$. tsunomi recorded olong the coost of kyushu. (BRK). Minor domoge (V JMA) in the Onahomo-Wotori orea. Felt (IV JMA) ot fukushima, Sendoi ond Tokyo; (111 JMA) of Niigoto, Maeboshi, and Yokohoma; (II JMA) of Hachinohe and Ajiro, Honshu ond Obihiro. Hokkoido. Felt (I JMA) from Shizuoko, Honshu to Kushiro. Hokkaido ond on Hochijo-jima. Depth from broodbond displocement seismogroms.

NEAR EAST COAST OF HONSHU, JAPAN. MS 6.6 (PAS), 6.4 (BRK). Silight domoge ( $V$ JMA) ot Shi rokowo. Feli (iv JMA) of Fukushimo, Mito ond Onohomo; (111 JMA) from the Tokyo-Kofu-Toteyomo areo to Miyoko and Morioko: (I) JMA) in the Maeboshi-Niigoto-Akito oreo ond of Kushiro. Hokkoido. Felt (I JMA) on Hochijo-jimo and Oshimo and from Shizuoko. Honshu to Hokodote and Urakowo. Hokkaido. Depth from broodbond displocement se i smogroms.

NORTHERN SUMATERA. MS 6.3 (PAS). TWO pEOPle killed, 22 injured and more than 300 buildings domaged in the Tarutung-loke roba oreo. hot spring in the oreo stopped flowing but resumed loter. Felt in the Sibolga-Berostagi oreo. Also felt in the Kuolo Lumpur oreo, Maloysio. 


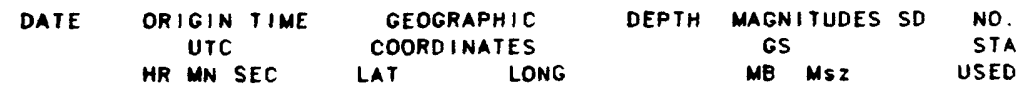

mar 02
LAT

LONG
1.3204

REGION, CONTRIBUTED MAGNITUDES AND COMMENTS

NORTHERN ITALY. ML 5.2 (FUR), 5.0 (LDG), 5.0 (TTG). ONE person died from o heort ot tock ot Pormo. Several people injured and slight damoge (VII) in the Reggio nell. Emilia-Modeno oreo. Felt from Lucco and Genoo 10 Milan, Verona and Podovo.

MAY $06040614.151 .272 \mathrm{~N} \quad 179.898$ W 20 G $6.36 .4 \quad 1.0477$ ISLANDS, ALEUTIAN IS, ML 6.1 (PMR), MS 6.5 (BRK), 6.2 (PAS). Felt (V) on Adok. Depth $\mathrm{fr}$ om broodband displocement seismogroms.

MAY OT $030549.146 .736 \mathrm{~N} 139.232$ E $430 \mathrm{G} 6.0$

0.9653 NEAR E. COAST OF EASTERN USSR, mb 6.6 (BRK), 6.5 (PAS)

Felt (IV) in ports of the Sikhote-Alin mountoin ronge.

Felt (II JMA) ot Aomori. Hochinohe. Morioko ond Miyoko; ( I JMA) of Akito, Tokodo. Tokyo ond Yokohomo. Honshu. Felt (II JMA) of Kushiro ond Urokowo: (I JMA) ot wokkonai, Rumoi and Asohikowo. Hokkoido. Two events about seconds oport. Depth from broodbond displocement seismogroms, bosed on first event.

MAY $12013025.0 \quad 7.090 \mathrm{~N} \quad 126.701$ E 25 G $6.26 .4 \quad 1.1455$

MINDANAO. PHILIPPINE ISLANDS. MS 6.5 (BRK), 5.9 (PAS) Felt (1) RF) of Cogoyon de Oro. Also felt at Polo. Leyte. Depth from broodbond displocement seismograms.

MAY 18

072700 .

$8.302 \mathrm{~N}$

$125.362 \mathrm{E}$

$16 \cdot 5.55 .9$

1.3

82

MINDANAO, PHILIPPINE ISLANDS. One person killed in Bukidnon Province. Felt (III RF) ot Cogoyon de oro. Also felt in the Dovao oreo.

Mar

$8.047 \mathrm{~N} \quad 125.410 \mathrm{E}$

32

5.15 .21 .2

99

MINDANAO, PHILIPPINE ISLANDS. One person wos killed, two people injured and domoge in the rolokog-Moloyboloy oreo. Fell (II RF) ot Cogayon de Oro and (I RF) ot Butuon and Surigoa.

173 SOUTHERN INDIANA. 〈SLM-P>. MbLg 5.1 (SLM), MS 4.6 (BRK). One person injured and minor domoge (VI) of Lowrenceville, Illinois. Minor domoge olso reported ot Bridgeport, Me. Cormel ond Olney, llinois: Bloomfield and New Albony. Indiono: and Louisville, Kentucky. Felt in parts of 21 stotes from Konsos to Pennsylvonio and from South Corolino to Minnesoto. Also felt in southern Ontorio. Conodo.

SEA, MS 6.8 (BRK), 6.5 (PAS), mb 6.3 (PAS). Fel on Bondo ond Ambon. Depth from broodbond displocement se $i$ smogr oms.

LUZON. PHILIPPINE ISLANDS. Eight people killed, five injured, one missing and live houses domoged from landslides. Felt ( $V R F$ ) in the epicentrol oreo: (IV RF) of Boguio: ( 1 II RF) of Monilo and cogoyon; (II RF) ot Sonto ond Iuguegar 00

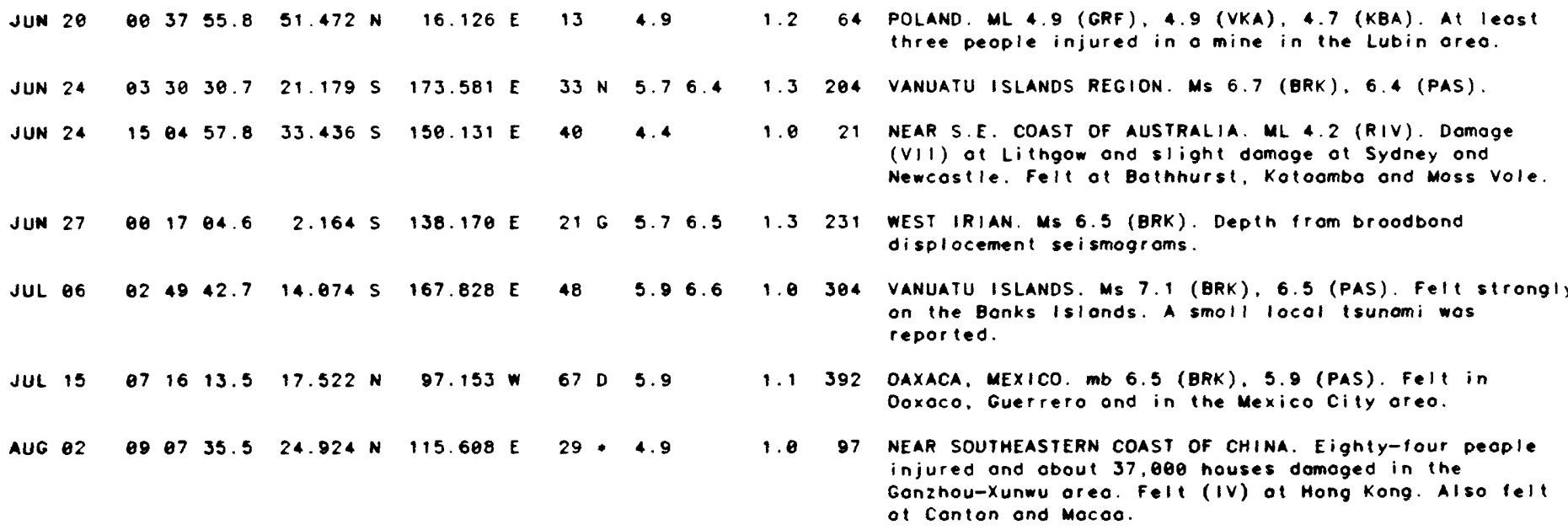


ORIGIN TIME UTC HR MN SEC
GEOGRAPHIC COORDINATES LAT LONG
DEPTH MAGNITUDES SD

$$
\text { GS }
$$$$
\text { MB MsZ }
$$

$1548 \quad 56.7 \quad 19.022$ S $69.991 *$ $\begin{array}{lllll}70 G \quad 6.4 & 6.9 & 1.1 & 379\end{array}$
AUG $13 \quad 152306.9 \quad 17.897 \mathrm{~s} \quad 70.931 \mathrm{~W} \quad 37 \mathrm{G} \quad 6.16 .4 \quad 1.2 \quad 310$ AUG $14062404.6 \quad 43.734 \mathrm{~N} \quad 20.413 \mathrm{E} \quad 14 \quad 5.0 \quad 198$ SEP 03

SEP 03

SEP 04

SEP 07

SEP 22

134337.6

$0.978 \mathrm{~S}$ $\begin{array}{llllll}33 & N & 5.8 & 6.7 & 1.3 & 249\end{array}$ $10 \mathrm{G} \quad 6.16 .2 \quad 1.0 \quad 306$
$158.513 \mathrm{E}$

$159.005 \mathrm{E}$

$13.874 E$
$33 \mathrm{~N} 5.97 .3 \quad 1.0 \quad 292$

$\begin{array}{llll}33 & 6.16 .8 & 1.2 & 275\end{array}$

$\begin{array}{lllll}19 & 5.14 .6 & 1.2 & 225\end{array}$
SEP 22

SEP 28

SEP 28

OCT 01
162135.

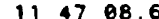

$\begin{array}{llll}1346 \quad 13.9 & 18.546 \mathrm{~S}\end{array}$

$144220.0834 .060 \mathrm{~N}$
NORTHERN CHILE. mb 6.3 (BRK). Five peOple killed, 112 injured and more thon 1.000 houses destroyed (Vii) in the Arico oreo. Severol londslides occurred olong the Chile-peru border. Domoge (VI) ot lquique. Felt (v) ot Tocopilla and $(111)$ at Colamo ond Antotogosto. Felt (III) at Lo Paz, Bolivia. Felt strongly ot Tocno, Moquequo and Limo, Peru. Appeors to be two events obout 5 seconds oport. Depth irom broodband displocement se ismogroms, based an first event.

NEAR COAST OF PERU. MS 6.2 (BRK). One person killed, one injured and additional domoge (V) ot Arica, Chile. Felt (IV) ot Arequipo and Tocno, Peru. Depth from broodbond displocement seismograms.

YUGOSLAVIA. ML 4.7 (TTG). Two people injured and domage (VII) in the Kroljevo-Bogutovocko Banjo oreo. Felt (III) ot Belgrade and in northern Montenegro. Felt (IV) in the Solio-pernik-vidin oreo, Bulgorio.

MACOUARIE ISLANDS REGION. MS 7.7 (BRK), 6.9 (PAS). MACOUARIE ISLANDS REGION

CENTRAL ITALY. ML 4.7 (VKA), 4.7 (LDG), 4.7 (TRI). MO 5.1 (TTG), 4.8 (KBA). Two people injured and damoge ( $V I 11$ ) in the Porto San Giorgio-fermo-Pedoso oreo. Same damage in the Civitanovo Marche-Porto Recanati area. Felt from Pesoro to Compobosso.

KERMADEC ISLANDS REGION. MS 6.7 (BRK).

ECUADOR. MS 6.1 (BRK). At leost two people killed. twelve injured, several houses destroyed or seriously domoged and londslides in the Amboto oreo. Minor domoge in the Lotocungo ond Riobombo oreo. Felt in southern Colombio ond northern Peru.

ECUADOR. Additionol domoge in the Amboto oreo. Fell strongly in the Lotocungo oreo. Felt in southern colombio and northern peru.

VANUATU ISLANDS. MS 6.7 (BRK), 6.7 (PAS). FeIt

vanuatu isLandos

292 SOUTHERN CALIFORNIA. SPAS-P). ML 5.9 (PAS), 6.1 (BRK) Eight people killeo. mony injureo, obout 2,200 homeless ond more thon 10,400 buildings damoged in the Los Angeles-Whitlier-posodeno oreo. The eorthquoke coused 358 million dollors in property domoge. Moximum intensity (VIII) ot Whittier. Felt strongly in much of southern colifornio. Felt os for awoy os Los Vegos. Nevodo.

DCT $02 \quad 222755.8 \quad 8.143 \mathrm{~S} \quad 77.954 \% 20 * 5.45 .1 \quad 1.0 \quad 144$ PERU. Three people killed ond severol homes domoged ot Sontiogo de Chuco. Felt (IV) at Trujillo ond (III) ot Chimbote.

OCT $64 \quad 105938.1834 .070 \mathrm{~N} \quad 118.100 \mathrm{~W} \quad 8 \quad 5.24 .8$

151 SOUTHERN CALIFORNIA. LPAS-P>. ML 5.3 (PAS), 5.6 (BRK) One person died from a heart ottock. Same injured ond odditionol damoge in the Pasodeno-Alhambro-Whittier oreo. Fell from Venturo County to Son Diego to Polm Springs.

$\begin{array}{llllllllllllll}\text { OCT } 06 \quad 04 & 19 & 06.0 & 17.940 & \mathrm{~S} & 172.225 & 17 & 16 & 6 & 6.7 & 7.3 & 1.0 & 455\end{array}$

TONGA ISLANDS REGION. MS 7.3 (BRK), 7.2 (PAS). Felt ot Nukuolofo. Felt on Americon Somoo. Twenty-tive $\mathrm{cm}$. isunami recorded ot Pago Pago, American Samoo.

$\begin{array}{lllllllllllll}\text { oct } 12 & 1357 & 04.7 & 7.288 & \mathrm{~S} & 154.371 & \mathrm{E} & 25 & 6.3 & 6.8 & 1.1 & 363\end{array}$
SOLOMON ISLANDS. MS 6.8 (BRK), 6.7 (PAS). Felt (V) ot Arowo ond Panguno, Bougoinvilie. Felt (iil) at Rabaul. New Britoin. Eight $\mathrm{cm}$. Isunomi recorded ot Roboul.

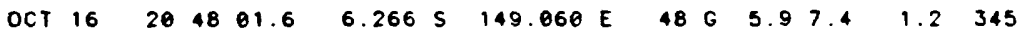

NEW BRITAIN REGION. MS 7.7 (BRK), 7.0 (PAS). DOMOge (VIII) ot Kondrion. Felt (V) ot Kimbe and Hoskins, (IV) ot Biallo ond (III) at Raboul. Felt (V) ot Finschioten and olso felt of Port Moresby. New Guineo. Felt (IV) on Bougoinville. Locol isunami generoted with 30 meter runup reported of Kondrion. Thirteen $\mathrm{cm}$. Isunomi recorded of Roboul. Multiple event. 


$\begin{array}{cccccc}\text { DATE ORIGIN TIME } & \text { GEOGRAPHIC } & \text { DEPTH MAGNITUDES SD NO } \\ \text { UTC } & \text { COORDINATES } & \text { GS } & \text { STA } \\ \text { HR MN SEC } & \text { LAT MONG } & \text { ME MSZ } & \text { USED }\end{array}$

NEAR COAST OF NICARAGUA. mb 6.2 (PAS). Three people injured and damoge in the Chinondego-Lean-El Viejo oreo, Nicaragua. Felt throughout Nicaroguo ond (IV) at Son Solvador. El Solvodor. Also felt in Honduras. Guatemala and northern Costa Rico.

NOV $17 \quad 68 \quad 4653.3858 .586$ N 143.270 W $10 \quad 6 \quad 6.6 \quad 6.9$

NOV 24

$015414.5433 .683 \mathrm{~N} 115.775 \% 505.76 .2$
581 GULF OF ALASKA. CAGS-P>. ML 7.0 (PMR). MS 7.0 (BRK) 6.8 (PAS). Complex event. Fett (V) ot Anchoroge. Haines, Seword. Tropper Creek, Valdez and Yokutat. Felt (iv) throughout much of southern lasko from Juneou to Anchorage. Also felt (IV) ot Whitehorse, Yukon Territory. Felt ot Kodiok, Alasko and Corcross and Hoines Junction, Yukon Territory. Ten $\mathrm{cm}$. tsunomi recorded of rakutot.

237 SOUTHERN CALIFORNIA. LPAS-P>. ML 5.8 (PAS), 6.5 (BRK). Two people killed in on eor thquoke-related outomobile occident obout $80 \mathrm{~km}$. eost of Mexicoli. Mexico. Slight domoge (Vi) ol Calipotrio. El Centro. Heber ond Westmorland. Felt throughout much of southern California from Son Diego and Los Angeles to Las Vegos. Mevodo and Yumo, Arizono. Also felt ot Mexicali. Tijuano and Ensenado, Mexico.

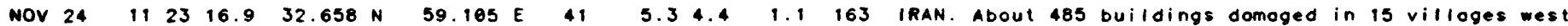
of Birjand. Felt ot Birjand and Doen.

NOV $24131556.4433 .010 \mathrm{~N} 115.840 \mathrm{~W} 226.06 .6$ Multiple event. At leost 94 people injured and on estimoted 4 millian dollars domage in Imperial County. Additianol injuries ond damoge occurred in the Mexicali area, Mexica, with on estimoted 3,000 people temporarily homeless. Maximum intensities (vi-vil) ot El Centro ond Westmorland, (VI) ot Browley, Colexico. Colipotria, Heber. Holtville, Imperiol ond Seeley. Felt throughout much of southern Californio tram San Diego ond Los Angeles to Las Vegas. Nevodo ond Tempe. Arizano. Also felt ot Tijuano and Ensenodo. Mexico. Surtace foult rupture ond ofterslip were mopped by California division of Mines and Geology olong $23 \mathrm{kil}$ ometer segment of the Superstition Hills foult. A moximum of 65 centimeters of rightloteral displocement with o few centimeters of vertical displocement was meosured. Strong-motion records indicate peak accelerotions of 0.219 at westmorland and $0.36 \mathrm{~g}$ at El Centro.

Nov 26

$\begin{array}{lllllllllllll}0143 & 14.0 & 8.247 \mathrm{~S} & 124.155 \mathrm{E} & 33 \mathrm{~N} & 5.8 & 6.5 & 1.3 & 158\end{array}$

TIMOR. Ms 6.3 (BRK), 6.3 (PAS). At leost 37 people killed, 108 injured and 237 buildings domoged on pantor lsland. Londslides also occurred on the islond. Mount sirung storted erupting an December 2 .

Nov 27

$\begin{array}{lllllllllll}08 & 26 & 43.7 & 32.691 & \mathrm{~N} & 59.100 & \mathrm{E} & 33 \mathrm{~N} & 4.7\end{array}$

6. 7

50

IRAN. ML 4.4 (MHI). Two hundre domoged in the Birjand oreo.

Nov 30

$192319.5 \% 58.679 \mathrm{~N} \quad 142.786 \mathrm{~W} \quad 10 \mathrm{G} \quad 6.77 .6$

584 GULF OF ALASKA. SSPEC). MS 7.7 (BRK), 7.4 (PAS). ML 7.1 (PMR). MO=1.2*10*20 Nm (BRK). Held to foreshock location. Damoge (VI) ot rokutot from eorthquoke ond tsunami. Felt (v) ot Anchorage, Copper Center, Gokono, Hoines. Homer. Juneou, Levelock, Petersburg. Seword ond Skwentno. Also felt (V) in sections of whitehorse, Yukon Territory, Conado. Felt (IV) throughout southern Alosko from the ketchikan area to Glennollen and kodiok Islond and $(111)$ as far awoy os Bethel and Foirbanks. Also felt at Sond Point ond (II) ot Anaktuvuk Poss. Some domoge coused to 2 ships at seo in the epicentrol oreo: felt strongly on 3 other ships in the oreo. Tsunami generated with wove heights (peok to trough) $85 \mathrm{~cm}$. ot Yokutot ond $25 \mathrm{~cm}$. ot Sitko, Alasko; $15 \mathrm{~cm}$. ot $\mathrm{Hil}$. $12 \mathrm{~cm}$. ot Nowiliwili and $5 \mathrm{~cm}$. ot Honolulu, Howaii; and $5 \mathrm{~cm}$. ot Presidio, Californio. Complex event. with mojor subevent occurring obout 15 seconds ofter onset of the foreshock. observed on broodbond displocement seismograms.

DEC 07 $\begin{array}{lllllll}12 & 26 & 11.7 & 13.632 & 5 & 167.393 \text { E } 48\end{array}$ $5.76 .2 \quad 1.0201$

VANUATU ISLANDS. MS 6.7 (BRK)

DEC 07 $131434.913 .559 \mathrm{~S} \quad 167.454 \mathrm{E}$ $33 \times 5.86 .3$ $1.0 \quad 230$ VANUATU ISLANDS. MS 6.7 (BRK)

DEC 17

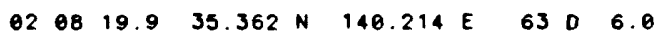

NEAR EAST COAST OF HONSHU, JAPAN. MS 6.4 (BRK). Two people killed, 66 injured and domoge in Chibo Prefecture and the Tokyo oreo. Felt (V JMA) ot Choshi, Chibo and Katsuuro; (IV JMA) in the Tokyo-Yokohomo-Mito-Kumogoyo oreo: (111 JMA) in the Onahomo-Shizuoko-lido oreo and on Oshimo and Hochijo-jima. Felt (I JMA) from Tottari to Sendoi.

SOUTH OF BALI ISLAND. Twenty people injured on Bali: Felt $(111)$ on Lambok and in eastern Jova. Depth from broodband displacement seismograms. 